\title{
FROM ENFORCEMENT TO INTEGRATION: INFUSING ADMINISTRATIVE DECISION- MAKING WITH HUMAN RIGHTS VALUES
}

\author{
Jennifer Raso*
}

This article proposes an integration approach to realize human rights values within administrative agencies. Using social assistance as a factual context, it examines how rights enforcement has become the dominant mechanism for reforming government benefits programs. Rights enforcement is ineffective at achieving the values underlying human rights codes, however, even where enforcement occurs at administrative tribunals. Attention must therefore be directed towards efforts to infuse individual and institutional discretion with human rights values. Given their quasi-constitutional status, such values have a key role to play in shaping the design of administrative agencies and the everyday decisions of front-line workers.

Dans ce document, l'auteur propose une approche axée sur l'intégration des droits afin d'assurer le respect des valeurs qui sous-tendent les droits de la personne à l'intérieur des organismes administratifs. En se servant de l'aide sociale comme toile de fond, l'auteur explique que la plupart des décisions discrétionnaires prises dans le cadre de l'exécution des droits ne sont pas contestées. Les mécanismes d'exécution des droits ne permettent pas d'assurer le respect des valeurs qui sous-tendent les droits de la personne, notamment en ce qui concerne les programmes d'avantages sociaux du gouvernement. En conséquence, il faut tenter d'intégrer ces valeurs aux décisions administratives discrétionnaires prises au niveau tant personnel qu'institutionnel. En raison de leur statut quasi constitutionnel, ces valeurs ont un rôle clé à jouer pour façonner la conception des organismes administratifs et les décisions que les travailleurs de première ligne sont appelés à prendre tous les jours.

\section{INTRODUCTION}

Since their introduction, statutory human rights codes and the administrative architecture that supports them have evolved in the pursuit of ameliorative and transformative goals. ${ }^{1}$ Rather than punish those who at some past point engaged in unlawful discrimination, human rights codes are today designed to remedy specific instances of discrimination and to prevent future discrimination in areas historically

* BA, LLB, SJD Candidate, Faculty of Law, University of Toronto. This article has benefitted greatly from the insightful comments of Denise Réaume, Audrey Macklin, Sylvia Rich, and its anonymous reviewers. I am also grateful to the graduate students and faculty at the University of Toronto's Centre for Criminology and Sociolegal Studies and participants at the 2014 annual meetings of the Law and Society Association and the Canadian Law and Society Association, who provided thoughtful feedback on early stages of this research, as well as to the Social Sciences and Humanities Research Council for its support.

1 The value of forward-looking approaches to human rights was noted by Chief Justice Dickson in his discussion of the need for proactive, systemic human rights remedies to prevent future discrimination: Action Travail des Femmes $v$ Canadian National Railway Co, [1987] 1 SCR 1114 at 1145, [1987] SCJ No. 42 (QL). 
plagued by it, such as housing, employment, and goods and services. ${ }^{2}$ Many of these codes announce broad policy goals, such as creating a "climate of understanding and mutual respect for the dignity and worth of each person". ${ }^{3}$ To achieve these goals, governments have experimented by establishing a range of administrative supports, including multi-purpose human rights commissions. As gatekeepers to the process for resolving human rights claims, early versions of commissions investigated and forwarded complaints to be heard by specialized boards and tribunals. Commissions also provided legal services to those with rights claims, represented complainants at hearings, initiated and pursued systemic discrimination claims, and developed policy and education initiatives to promote broader social cooperation, inclusiveness, and respect for diversity. ${ }^{4}$

While human rights commissions may have signaled a commitment to a sophisticated strategy for realizing the ameliorative goals of human rights codes, delays in commission-driven processes ultimately contributed to government decisions to reduce the role of multi-purpose commissions in favour of an "enforcement" approach to rights. ${ }^{5}$ Public attention and institutional reform efforts thus retreated from commission-centred strategies for preventing human rights violations to instead focus on litigating individual cases. Litigation at administrative tribunals, and to a lesser extent courts, now appears to be the preferred mechanism for advancing rights, and rights enforcement seems to be the main driver behind much human rights scholarship and advocacy efforts. By "rights enforcement", I mean approaches that use litigation as the primary means of accomplishing the goals of human rights codes. Rights enforcement's dominance as a tool for achieving legal, social, and political change is particularly evident in recent moves to increase the availability and use of enforcement mechanisms at administrative tribunals. Paradoxically, this shift has occurred at a time when there is extensive research questioning litigation's ability to achieve the broad reformist goals of human rights. ${ }^{6}$

The shortcomings of rights enforcement are especially apparent in government benefit programs such as social assistance. 7 The practice of "enforcing" rights through litigation offers illusive gains for social assistance recipients. Barriers to rights enforcement, including financial and emotional costs, delays in resolving claims, complex jurisdictional questions, and the onerous legal tests that are common in rightsbased challenges to government benefits programs, impede the successful enforcement of the rights of

2 Rosanna L Langer, Defining Rights and Wrongs: Bureaucracy, Human Rights and Public Accountability (Vancouver: University of British Columbia Press, 2007).

3 Human Rights Code, RSO 1990, c H19, Preamble [Code].

$4 \quad$ Langer, supra note 2.

5 The many reasons behind the delays experienced by human rights commissions are beyond the scope of this article. However, they are canvassed elsewhere including J Manuel Mendelzon, "Rights, Remedies and Rhetoric: On a Direct Access Model for Human Rights Complaints in Ontario” (2008) 6:1 JL \& Equality 51; Heather M MacNaughton, "Human Rights Reform: Again?" (2011) 74 Sask L Rev 235; Blencoe v British Columbia (Human Rights Commission), 2000 SCC 44, [2000] 2 SCR 307, [2000] SCJ no 43 (QL).

6 Kimberlé Williams Crenshaw, "Race, Reform, and Retrenchment: Transformation and Legitimation in AntiDiscrimination Law" (1988) 101:7 Harvard L Rev 1331; Paul D Butler, "Poor People Lose: Gideon and the Critique of Rights" (2013) 122:8 Yale LJ 2176. In Canada, Dominique Clément has challenged the dominance of formal legal accounts of the rise of rights with a focus on the significance of grassroots movements in achieving rights-inspired social and political change: Dominique Clément, Canada's Rights Revolution: Social Movements and Social Change, 1937-82 (Vancouver: UBC Press, 2008).

7 By "social assistance", I refer to both welfare and disability support programs. In Ontario, these programs are also known as Ontario Works and the Ontario Disability Support Program, respectively. 
social assistance recipients. Additionally, the unequal power between those who rely on social assistance and the administrative actors who distribute benefits essentially thwarts the possibility that rights enforcement might, on its own, improve how social assistance recipients experience and are treated by a government benefits program that purports to meet their basic needs. The deeply troubling consequence of all of this is that, in the context of social assistance, rights enforcement's limits disadvantage the very people that human rights codes were designed to protect: newcomers, racialized minorities, sole-support mothers, and persons with disabilities. ${ }^{8}$

This article explores how rights enforcement, as a dominant and often stand-alone strategy, falls short of realizing the ameliorative aspirations behind human rights codes. Drawing on recent attempts to improve access to rights enforcement mechanisms in Ontario, including the introduction of a directaccess human rights tribunal and the post-Tranchemontagne expansion of tribunals that will hear and determine human rights issues, ${ }^{9}$ I examine how barriers to rights enforcement persist and interrelate in ways that frustrate the possibility of achieving institutional and social change. To illustrate some of rights enforcement's shortcomings, I reflect on recent decisions of both the Human Rights Tribunal of Ontario [HRTO] and the Social Benefits Tribunal [SBT], as well as legal and socio-legal literature examining the relationship between law and social change.

In response to rights enforcement's limitations, I propose that enforcement strategies must be paired with a strategy of rights integration so that infusing human rights values into the routine decisions of those who administer government benefits programs becomes an ongoing concern for social justice advocates, rights claimants, and administrative actors. "Human rights values" include the transformative goals on which statutory human rights codes are founded, such as an improved understanding of and mutual respect for the dignity and worth of each member of society. ${ }^{10}$ Realizing these values does not require abandoning rights enforcement entirely. However, it does demand that sufficient creative scholarly and organizational energy be directed towards a broader set of strategies to transform the relationship between those reliant on government benefits and those empowered to administer such benefits. In the context of social assistance, a rights integration approach would harness the extensive discretion that characterizes government benefits programs. ${ }^{11}$ Though discretion can be exercised in ways that are detrimental to the well-being of society's most marginalized members, it also provides a space within which human rights values, such as dignity and respect, can guide administrative decision-making at individual and institutional levels. Rights integration, as an essential

8 Human rights codes are designed to protect people who belong to groups that have historically suffered discrimination and marginalization; members of these groups are disproportionately reliant on social assistance benefits: Ontario, Commission for the Review of Social Assistance in Ontario, Brighter Prospects: Transforming Social Assistance in Ontario (Toronto: Queen's Printer, 2012) [Brighter Prospects] at 13. See also National Council of Welfare, Profiles of Welfare: Myths and Realities (Ottawa: Public Works and Government Services Canada, 1998).

9 Tranchemontagne v Ontario (Director, Disability Support Program), 2006 SCC 14, [2006] 1 SCR 513, [Tranchemontagne].

10 Code, supra note 3. See also Leslie Reaume, "Postcards from O’Malley: Reinvigorating Statutory Human Rights Jurisprudence in the Age of the Charter" in Fay Faraday, Margaret Denike \& M Kate Stephenson, eds, Making Equality Rights Real: Securing Substantive Equality under the Charter (Toronto: Irwin Law, 2006) 373.

11 Kenneth Culp Davis, Discretionary Justice: A Preliminary Inquiry (Baton Rouge: Louisiana State University Press, 1969) at 4. See also Evelyn Brodkin, "Inside the Welfare Contract: Discretion and Accountability in State Welfare Administration" (1997) 71:1 Social Service Rev 1. 
counterpart to rights enforcement, calls for more than the reform of the laws and policies regulating government benefits; rather, it requires shifts in social and institutional attitudes.

This article proceeds in three parts. Part II demonstrates how rights enforcement has become the dominant strategy for realizing rights, drawing on two examples: the recent reform of Ontario's human rights agencies; and, the change wrought by the Supreme Court of Canada's decision in Tranchemontagne. Part III canvasses the obstacles to rights enforcement as an effective stand-alone strategy for realizing the ameliorative ambitions of human rights codes. While rights litigation may play a symbolic role in the struggle for a more equitable and just society, costs, delay, jurisdictional limits, and difficult legal tests combine with the uneven power dynamic between rights claimants and government respondents to frustrate the achievement of tangible, dignity-promoting institutional reforms. Part IV proposes rights integration as a necessary counterpart to rights enforcement and identifies administrative discretion as a site for scholarly study and advocacy efforts. Using Ontario's social assistance program, this section illustrates how discretion is widespread, existing whenever polycentric decisions are made and rules are applied. While discretion can allow discrimination to creep into administrative decisions, it can also provide administrative decision-makers with an opportunity to foster participatory, respectful decision-making. This article closes with some thoughts about how individual and institutional discretion might be harnessed along with rights enforcement efforts to work towards the transformative goals of human rights codes.

\section{THE DOMINANCE OF RIGHTS ENFORCEMENT}

Rights enforcement has become established as the dominant strategy for realizing rights. Two examples, considered below, illustrate this phenomenon: the introduction of a direct-access human rights tribunal in Ontario; and, the widening of other administrative tribunals' jurisdiction to hear and determine human rights issues post-Tranchemontagne.

\section{A. Direct-Access Human Rights Tribunals Introduced}

In recent decades, human rights tribunals and commissions have been reviewed and restructured so as to reduce institutional delay, increase the use of mediation, and provide claimants with the opportunity to submit their human rights claims directly to tribunals. These transformations occurred in response to the very real and substantial delays that plagued commission-based human rights regimes, particularly in British Columbia and Ontario. ${ }^{12}$ Though intended to improve the timely resolution of human rights disputes, these reforms also cemented rights enforcement's place as the main mechanism for achieving the promise of human rights codes at the expense of alternative strategies aimed at more deeply integrating human rights values into social and institutional attitudes and processes.

At one time, multi-purpose human rights commissions were a central feature of Canadian human rights regimes. Commissions acted as gatekeepers to the formal dispute resolution mechanisms available under human rights codes, investigating and mediating complaints, advancing claims supported by a sufficient factual record to a board or tribunal hearing, and representing complainants at administrative hearings. Importantly, commissions also furthered the transformative goals of human

12 See Langer, supra note 2; Brian Etherington, "Promises, Promises: Notes on Diversity and Access to Justice" (2000)

26:1 Queen's LJ 43; William Black, "Delays in the Human Rights Process: The Blencoe Case” (2001) 13:1 CJWL 172. 
rights codes in a variety of other ways, serving as educators, interveners, and policy-makers. ${ }^{13}$ For a number of reasons, however, commissions became plagued by lengthy delays in their investigation and forwarding of complaints to tribunal hearings, which jeopardized claimants' ability to have their complaints heard and resolved in a timely manner. ${ }^{14}$

In response, a number of government panels were struck to examine the state of human rights regimes. Many of the resulting reports recommended eliminating some commission tasks and allowing claimants direct access to human rights decision-makers. ${ }^{15}$ These recommendations rested on the assumptions that directly-accessible tribunals would contribute to the more timely and effective resolution of human rights claims and, relatedly, that the resolution of individual claims was a suitable mechanism for achieving the wider policy goals of statutory human rights regimes. Direct-access tribunals, it was thought, would contribute more effectively to realizing human rights than had the previous commission-as-gatekeeper model. As a result, British Columbia eliminated its Human Rights Commission entirely, leaving a direct-access human rights tribunal in its place. Shortly thereafter, Ontario restructured its human rights regime. Not only did Ontario establish a direct-access tribunal and a new legal support centre to assist individuals with commencing human rights claims, it considerably reshaped its Human Rights Commission by removing the Commission's gatekeeper function. The Ontario Human Rights Commission [OHRC] retained its mandate to develop human rights policy, however, as well as the authority to initiate its own applications and intervene in others before the HRTO. $^{16}$

This restructuring of the administrative architecture supporting Ontario's human rights regime represented a turn to rights enforcement. Although the OHRC maintained policy, education, and advocacy functions that it could use to pursue alternative rights realization strategies, cuts to the Commission's staff and resources jeopardized its ability to proactively tackle the deeper systemic inequities that can go unaddressed in individually driven rights claims. ${ }^{17}$ As the Commission's resources diminished, resources and staff available to the HRTO and Ontario's new legal support centre for rights claimants grew substantially, marking the ascendance of rights enforcement. Though direct-access tribunals and legal resource centres may, at first glance, appear to advance rights, the simultaneous reduction of commission responsibilities and resources left an inadequate set of tools available to achieve the transformative promise of human rights codes.

13 Langer traces the history of the OHRC's evolution, supra note 2 at 1-24.

14 The reasons for these delays is beyond the scope of this article, but see Langer, ibid; Mendelzon, supra note 5; and David Johnson \& R Brian Howe, "Human Rights Commissions in Canada: Reform or Reinvention in a Time of Restraint?" (1997) 12:1 CJLS 1 .

15 Direct access to human rights tribunals was recommended for human rights tribunals in Ontario, British Columbia and federally in each of the following reports: Ontario Human Rights Code Review Task Force, Achieving Equality: A Report on Human Rights Reform (Toronto: Ontario Human Rights Commission, 1992); British Columbia Human Rights Review, Report on Human Rights in British Columbia (Vancouver: Ministry Responsible for Multiculturalism and Human Rights, 1994); The Report of the Canadian Human Rights Act Review Panel, Promoting Equality: A New Vision (Ottawa: Canadian Human Rights Act Review Panel, 2000).

16 Mary Cornish, Fay Faraday \& Jo-Anne Pickel, Enforcing Human Rights in Ontario (Aurora: Canada Law Book, 2009) at 77-81.

17 Andrew Pinto, Ontario Ministry of the Attorney General, Report of the Ontario Human Rights Review 2012 (Toronto: Queen's Printer, 2012) at 120-23. 


\section{B. Other Tribunals Empowered to Decide Human Rights Claims}

As the administrative framework for realizing Code-protected rights was redesigned, court decisions increased the number and type of administrative decision-makers empowered to decide rights claims. This development appears to have been a response to the growing volume of rights claims that were being made to administrative decision-makers tasked with implementing government benefits programs, such as workers compensation and disability supports. ${ }^{18}$ Despite the ongoing efforts of rights claimants and social justice advocates, courts had proved themselves to be less than ideal settings for rights litigation aimed at improving the benefits and supports available to marginalized people. ${ }^{19}$ As a result, while human rights tribunals and commissions were being restructured, a surge of rights claims were raised to other administrative decision-makers challenging the unequal provision of government benefits. ${ }^{20}$ Energy and resources thus shifted from rights claims made in one litigation forum - courtbased Charter challenges - to tribunal-based Charter and human rights code challenges. ${ }^{21}$

From the early 1990s on, a series of court decisions expanded the authority of administrative tribunals to hear and determine first Charter and then human rights code issues, helping to establish rights enforcement as the central tool for realizing rights. ${ }^{22}$ Two assumptions lay beneath these court decisions: first, that a broader set of administrative decision-makers would be able to quickly and inexpensively determine rights issues; and, second, that these decision-makers would be well-positioned to use their expertise in particular government programs to design appropriate, effective remedies for rights violations.

The Supreme Court of Canada's decision in Tranchemontagne reinforced rights enforcement as a central strategy for reforming government benefits programs. In Tranchemontagne, the Court considered

18 These programs were the subject of two of the leading cases on the jurisdiction of other administrative decision-makers to decide questions involving the Charter, as in the cases of Nova Scotia (Workers' Compensation Board) v Martin and Nova Scotia (Workers' Compensation Board) v Laseur, 2003 SCC 54, [2003] 2 SCR 504 [collectively Martin], or statutory human rights codes, as in the case of Tranchemontagne, supra note 10.

19 Court challenges to government benefits programs have been largely unsuccessful, particularly claims that propose positive rights to state support: Hester Lessard, "Dollars versus [Equality] Rights: Money and the Limits of Distributive Justice" (2012) 58 SCLR 299. However, challenges targeting how eligibility for social assistance benefits is patrolled and confirmed have been met with greater success. For an unsuccessful challenge to the reduction of welfare benefits in Ontario, see Masse v Ontario (Ministry of Community and Social Services) (1996), 134 DLR (4th) 20 (Div Ct), [1996] OJ no 363 (QL) (leave to appeal to the Ont CA refused). For a similarly unsuccessful challenge to the provision of lower welfare benefits to welfare recipients based on age, see Gosselin v Québec (Attorney General), 2002 SCC 84, [2002] 4 SCR 429 [Gosselin]. For a successful challenge to Ontario's "spouse-in-the-house" rules, see Falkiner v Ontario (Ministry of Community and Social Services) (2002), 59 OR (3d) 481 (CA), 212 DLR (4th) 633. It should be noted that concerns also exist about the value of other avenues for realizing social and institutional change, such as legislative and policy reform: Margot Young, "Why Rights Now? Law and Desperation" in Margot Young et al, eds, Poverty: Rights, Social Citizenship, and Legal Activism (Vancouver: UBC Press, 2007) 318.

20 Claire Mummé, "At the Crossroads in Discrimination Law: How the Human Rights Code Overtook the Charter in Canadian Government Services Cases" (2012) 9 JL \& Equality 103.

21 Canadian Charter of Rights and Freedoms, Part I of the Constitution Act, 1982, being Schedule B to the Canada Act 1982 (UK), 1982, c11 [Charter].

22 Many of these Charter decisions are reviewed in Evan Fox-Decent \& Alexander Pless, "The Charter and Administrative Law: Cross-Fertilization or Inconstancy?" in Colleen M Flood \& Lorne Sossin, eds, Administrative Law in Context, 2d ed (Toronto: Emond Montgomery, 2013) 407. See, for instance, Martin, supra note 19; Tranchemontagne, supra note 10; $R$ v Conway, 2010 SCC 22, [2010] 1 SCR 765; Doré v Barreau du Québec, 2012 SCC 12, [2012] 1 SCR 395. 
whether the SBT, the specialized tribunal responsible for hearing social assistance appeals, had the jurisdiction to consider the Code. Not only does Tranchemontagne exemplify how rights enforcement can become fixed as a strategy for social and institutional change, but Justice Bastarache's majority judgment reflects the common assumption that improving access to decision-makers who are empowered to determine rights issues can make the progressive goals underlying human rights codes more tangible to vulnerable rights claimants. In Tranchemontagne, Norman Werbeski and Robert Tranchemontagne challenged the fact that their requests for disability benefits were denied solely because their disabilities arose from alcohol addictions. ${ }^{23}$ At the time of their applications for Ontario Disability Support Program [ODSP] benefits, the governing legislation specifically excluded those who were disabled due to alcohol or drug addiction. ${ }^{24}$ On appeal to the SBT, both men claimed that they were disabled within the meaning of the Ontario Disability Support Program Act, 1997, the legislation governing ODSP and, further, that excluding addicted persons from accessing disability benefits violated the Code. ${ }^{25}$ Rather than going to the OHRC, which was the route to a Code-based claim at the time of their appeals, Werbeski and Tranchemontagne incorporated their rights claims into their SBT appeals. The SBT declined jurisdiction to determine whether the ODSPA provision at issue violated the Code, and this question eventually made its way to the Supreme Court of Canada.

At the Supreme Court of Canada, the Court was divided on the issue of whether administrative decision-makers other than specialized human rights bodies could consider claims made pursuant to statutory human rights codes. The majority noted that fostering an administrative legal culture respectful of human rights was a central goal of the jurisprudence on the relationship between administrative decision-makers and human rights instruments. ${ }^{26}$ Given the quasi-constitutional status of human rights codes and their primacy over the laws governing social assistance, the majority confirmed that a tribunal that is authorized to determine questions of law can consider human rights code issues raised as part of an appeal that is otherwise within its jurisdiction. ${ }^{27}$ This would prevent marginalized individuals from having to split their claims between a tribunal empowered to determine appeals from a particular government benefits program and one specialized in deciding human rights claims. Such claim-splitting could have particularly dire consequences for those reliant on government assistance and vulnerable to the wrongful withholding of benefits. ${ }^{28}$ Letting other tribunals consider human rights code issues would make rights remedies more accessible to social assistance recipients and others dependent

23 Tranchemontagne, supra note 10.

24 The other half of Ontario's social assistance regime is what I refer to as "welfare": the supports offered through the Ontario Works program. ODSP is governed by the Ontario Disability Support Program Act, 1997, SO 1997, c25, Schedule B [ODSPA]. Ontario Works is governed by the Ontario Works Act, 1997, SO 1997, c25, Schedule A [OWA]. The provision in question was s 5(2) of the $O D S P A$, which reads: "5(2) a person is not eligible for income support if (a) the person is dependent on or addicted to alcohol, a drug or some other chemically active substance; (b) the alcohol, drug or other substance has not been authorized by prescription as provided for in the regulations; and (c) the only substantial restriction in activities of daily living is attributable to the use or cessation of use of the alcohol, drug or other substance at the time of determining or reviewing eligibility."

26 Tranchemontagne, supra note 10 at para 39.

27 Elizabeth Shilton notes that Tranchemontagne was unsurprising to scholars and lawyers working in labour law because human rights matters had long been incorporated into processes such as labour arbitration and collective agreement interpretation: "Choice but no Choice: Adjudicating Human Rights Claims in Unionized Workplaces in Canada" (2013) 38:2 Queen's LJ 461 at 469-71.

28 Tranchemontagne, supra note 10 at paras $12,48-50$. 
on government benefits, thus "bringing justice closer to the people." 29 Accordingly, the judgment affirms the centrality of individual enforcement efforts as the key to realizing rights.

The restructuring of the administrative framework within which Ontario's Code operates has secured a central place for rights enforcement while overshadowing alternate paths for rights integration. The introduction of a direct-access HRTO, establishment of a legal support centre for individual rights claimants, and judicial confirmation of other tribunals' jurisdiction to hear and determine human rights issues have effectively solidified rights enforcement's place as the primary mechanism for realizing rights. Critical scholarly and advocacy efforts have been redirected towards the myriad new options available for pursuing individual human rights claims and away from alternative strategies typically associated with human rights commissions, such as education campaigns or the development of institutional standards inspired by human rights values. As I will explore in the next section, given the persistence of barriers to rights enforcement, there is a need for renewed interest in alternative ways to infuse the values underlying rights into the everyday activities of administrative agencies.

\section{BARRIERS TO RIGHTS ENFORCEMENT}

Reforms to the administrative institutions and processes that claimants must use to enforce their rights are unlikely, on their own, to lead to the realization of the progressive goals of human rights codes. Even if rights claims can be heard by a larger number of administrative tribunals that purport to be faster and easier to use than courts, a number of obstacles prevent rights enforcement from being an effective stand-alone strategy. The main barriers to rights enforcement- including costs, delay, limited decision-making jurisdiction, and onerous legal tests - do not simply limit the systemic impact of individual rights claims, however. They point to deep-set flaws common to any administrative reform strategy that relies heavily on litigation. The effect of these barriers is intensified by the power disparities between rights claimants, who rely on government benefits to meet their basic needs, and the government respondents who provide these benefits. This section illustrates how each obstacle to rights enforcement can frustrate attempts to achieve the ameliorative goals of human rights codes in government benefits programs. Drawing on law and social change scholarship, I then consider how the uneven relationship between rights claimants and benefits-delivering agencies further limits rights enforcement's effectiveness.

\section{A. Costs and Delay}

First, the costs and delays common to litigation impede rights enforcement's ability to achieve broader goals of mutual understanding and respect, especially in government benefits programs. The emotional and financial costs of pursuing rights-based claims are magnified by the delays that individuals may experience in litigation. These delays can occur even when claims are pursued at ostensibly simpler, more efficient administrative tribunals. ${ }^{30}$ Allowing human rights claims to be brought directly to a variety of administrative decision-makers may have decreased the delays and costs

Ibid at para 52.

30 Lorne Sossin reviews some of the barriers to pursuing dispute resolution at administrative tribunals, including the effect of costs, in "Access to Administrative Justice and Other Worries" in Colleen M Flood \& Lorne Sossin, eds, Administrative Law in Context, 2d ed (Toronto: Emond Montgomery, 2013) 211. 
associated with previous commission-driven models, yet costs and delay persist at many administrative agencies that today resolve Code-based claims. ${ }^{31}$ No matter whether hearings occur at the HRTO or other bodies such as the SBT, they frequently involve many procedural steps - pre-hearing motions, case conferences, and production requests - that can defer the determination of a claim's merits and increase the financial and emotional cost to rights claimants. ${ }^{32}$ What is more, tribunal policies can impede the resolution of social assistance recipients' rights claims, especially when policies bifurcate hearings so that human rights issues are addressed only after a tribunal has determined that a particular benefits decision was correct. ${ }^{33}$ These costs and delays can be further exacerbated by the other barriers to rights enforcement explored below, such as confusion over whether a tribunal other than the HRTO has the jurisdiction to hear a human rights claim or grant particular remedies.

Though my focus here is on rights enforcement by way of claims to administrative tribunals, it is important to note that such claims can also lead to court proceedings. Where tribunal decisions are appealed or judicially reviewed, the delay and costs claimants experience are often magnified. Despite ongoing efforts at civil justice reform, court proceedings continue to impose significant financial burdens on litigants and may involve even lengthier timelines for dispute resolution than administrative proceedings. ${ }^{34}$ Further, court judgments are not self-enforcing. When a rights claimant succeeds in court, she must often return to the administrative decision-maker whose decision she appealed so that a new decision can be issued in compliance with the court's order. All of this extends the time it takes to resolve a rights claim and compounds the costs a claimant experiences.

31 Unclear data is available regarding the speed with which claims to the HRTO are resolved. While the HRTO seems to have made some progress in reducing the length of time it takes to schedule mediation and hearing dates or to release its decisions, it is uncertain how long it takes claims to move forward after they are first filed with the HRTO: Ontario, Social Justice Tribunals Ontario, 2013-2014 Annual Report (Toronto: Social Justice Tribunals Ontario, 2014) [SJTO 2013-14 Report] at 26-29. Delays may also be longer in claims challenging the provision of government benefits, which make up a small percentage of the HRTO's total caseload. For instance, when it comes to the HRTO, see the series of decisions that culminated in Hinsley v Ontario (Ministry of Community and Social Services), 2014 CanLII 587 (HRTO), in which two applicants sought to challenge the decision of their ODSP caseworker denying them funding to obtain a criminal pardon which would improve their chances of obtaining employment. In this case, initial requests for pardon funds were made in June and November 2011, but a final HRTO decision was not rendered until April 2014. Similar delays are common in SBT hearings involving human rights claims, with many appeals taking at least three years to resolve. See, for instance, SBT File No 0603-02193R (October 27, 2009) [unpublished, on file with author] and the collection of decisions discussed in Jennifer Raso, "Tranchemontagne Revisited: Examining Rights Accessibility through Administrative Aftermath" 12 JL \& Equality [forthcoming in 2015].

32 Both the HRTO and SBT's procedural rules provide for multiple pre-hearing procedures which, when used, can increase delay and associated costs for those with human rights complaints: see Human Rights Tribunal of Ontario, Rules of Procedure, online: Human Rights Tribunal of Ontario < http://www.sjto.gov.on.ca/hrto/rules-and-practice-directions/>; see also the Social Benefits Tribunal's eight Practice Directions and one Practice Tip regarding early resolution, online: Social Benefits Tribunal <http://www.sjto.gov.on.ca/sbt/rules-of-procedure/>.

33 Social Benefits Tribunal, Practice Direction 6 - Procedure Regarding Human Rights Code Issue or Challenge (February 1, 2010), online: Social Benefits Tribunal <http://www.sjto.gov.on.ca/sbt/rules-of-procedure/> [Practice Direction 6].

34 The persistence of costs and delay in court proceedings is well documented: Julia Bass, WA Bogart \& Frederick H Zemans, eds, Access to Justice for a New Century: The Way Forward (Toronto: Law Society of Upper Canada, 2005); Chief Justice Beverley McLachlin, “The Challenges We Face” (2008) 4:2 High Court Q Rev 33. The impact of costs and delay on middle income people have more recently been examined in Michael Trebilcock, Anthony Duggan \& Lorne Sossin, eds, Middle Income Access to Justice (Toronto: University of Toronto Press, 2012). 
Using Tranchemontagne as an example, seven and a half years elapsed between the dates on which Werbeski and Tranchemontagne were first denied disability benefits and the date when the SBT decided their human rights claims. ${ }^{35}$ During this time, both men received no disability benefits despite the fact that their alcohol addictions were so debilitating that they were unable to maintain paid employment. This is a high cost for enforcing one's human rights. In cases where claimants challenge government benefits decisions, costs and delay can thus be substantial barriers to rights enforcement. The costs claimants experience - a lack of meagre benefits to pay for food and shelter, the emotional toll and stress associated with unresolved claims - intensify the longer it takes enforcement proceedings to resolve their human rights complaints.

\section{B. Jurisdictional Limits}

The complex jurisdictional limits governing administrative tribunals are a second barrier to rights enforcement. When individual rights claims are used to reform programs such as social assistance, they often raise nuanced jurisdictional questions that can prevent the substance of such claims from ever being heard. For claimants who recognize that jurisdiction might be an issue, the intricacies of a tribunal's authority can frustrate their attempts to raise claims to the appropriate decision-maker. For others, jurisdictional problems may lead their claims to be dismissed on a technicality, leaving their substantive rights claims unaddressed. When these things happen, a significant sense of injustice and exclusion can develop for those whose claims are not heard. ${ }^{36}$ Jurisdictional barriers to rights enforcement can have particularly detrimental effects in government benefits programs, as those whose claims are not heard often must continue to receive benefits from a caseworker and a program that they experience as disrespectful and discriminatory.

Rights claims involving social assistance programs raise exceptionally complicated and counterintuitive jurisdictional questions, which can prevent specialized human rights tribunals and other tribunals such as the SBT from resolving them. The HRTO has a much broader mandate to hear and determine human rights matters than the SBT, yet its jurisdictional limits may still prevent it from addressing the substance of individual claims or granting remedies to prevent future discrimination. For instance, one cannot challenge a caseworker's misapplication of social assistance policies or an adjudicative decision denying her benefits as being contrary to the Code in a claim to the HRTO. Instead, she must frame her claim as a challenge to the way in which benefits are delivered in a particular office rather than as a challenge to a particular caseworker's discrete decision. ${ }^{37}$ The thin

35 These timelines are reviewed in the Divisional Court's decision on a second set of appeals stemming from Werbeski and Tranchemontagne's application for disability benefits: Ontario (Director, Disability Support Program) $v$

Tranchemontagne, [2009] 95 OR (3d) 327 (Div Ct) [Tranchemontagne, Div Ct].

36 This injustice is magnified for those reliant on social assistance. The program itself is notoriously difficult to navigate and often involves intense scrutiny, surveillance and eligibility verification requirements that leave those who need basic supports feeling dehumanized: Dean Herd \& Andrew Mitchell, "Discouraged, Diverted and Disentitled: Ontario Works New Service Delivery Model" (Toronto: Community and Social Planning Council of Toronto, 2002).

37 Ball v Ontario (Community and Social Services), 2010 CanLII 360 (HRTO); Zaki v Ontario (Community and Social Services), 2011CanLII 1797 (HRTO). The provision of benefits is a "service" under the Code, and thus benefits must not be provided in a discriminatory fashion. However, an adjudicative decision as to eligibility for benefits is not considered to be a "service" within the meaning of the Code and thus eligibility decisions cannot, on their own, be challenged as being unlawful instances of discrimination under the Code. 
distinction between the general practice of delivering benefits in a discriminatory fashion and specific benefit eligibility decisions can confuse and frustrate social assistance recipients, whose experience of discrimination may arise precisely from an individual caseworker's decision to grant or deny benefits. When it comes to remedies, the HRTO may be reluctant, for jurisdictional reasons, to award systemic remedies even in cases where social assistance providers have a history of using discriminatory policies to deny requests for basic benefits. ${ }^{38}$ Thus, regardless of whether claimants can now bring their claims directly to the HRTO or access the help of a specialized legal support centre, complex jurisdictional problems can still prevent them from having their Code claims resolved and remedied, inhibiting broader institutional change in the process. ${ }^{39}$

Jurisdictional questions pose similar problems for rights enforcement at other tribunals. At the SBT, for instance, the interaction between legislation and tribunal policy significantly limits the range of human rights issues that the SBT will hear and determine. Two examples - the legislative distinctions between benefits, and a tribunal policy that purportedly narrows the SBT's jurisdiction - are illustrative. First, the SBT can only decide those rights claims that are connected to an appeal that is itself within the SBT's jurisdiction. $^{40}$ In other words, a social assistance recipient cannot raise a stand-alone human rights claim to the SBT; all rights claims must be linked to a caseworker's decision to deny benefits. But social assistance recipients cannot appeal just any caseworker decision to the SBT. Social assistance legislation only allows for SBT appeals on a narrow set of decisions involving core benefits (shelter allowance, for example). Thus, while many other caseworker decisions could lead to the discriminatory delivery of social assistance - such as decisions about documentation requirements, extending application deadlines, or eligibility for a range of benefits that supplement the impossibly low basic living allowances in Ontario's social assistance programs - these decisions are not appealable to the SBT. ${ }^{41}$ As a result, human rights claims at the SBT are restricted to those involving a small set of benefit decisions. All other claims must be brought to the HRTO. Secondly, the SBT has further narrowed its own jurisdiction by establishing a policy that it will hear only those rights claims that

38 See Pennington v Peterborough (City), 2012 CanLII 1851(HRTO), in which an individual who was disabled but receiving welfare sought dentures to replace a large number of his missing teeth. His request for funding to cover the cost of dentures was denied based on a City of Peterborough policy that limited such benefits to only those individuals who were pursuing employment, which the applicant was not able to do because of his disability. The applicant sought, among other things, a prospective order from the HRTO preventing the City of Peterborough from implementing similar policies in the future but, as he had been provided with dentures and the subject policy was repealed by the time the HRTO heard his claim, this remedy was denied.

39 Indeed, while publicly-reported figures on the early dismissal of claims at the HRTO are not disaggregated based on the reasons for dismissal, some of these figures likely include claims dismissed for a lack of jurisdiction. Early dismissal is the fate that meets the majority of claims brought to the HRTO: SJTO 2013-14 Report, supra note 33 at 29.

40 For the majority decision's discussion of the SBT's jurisdiction, see Tranchemontagne, supra note 10 at paras 16-42.

41 SBT appeals are limited to decisions involving benefits that the $O W A$ and ODSPA deem to be centrally important, such as funding to cover the cost of shelter, food and clothing. Decisions regarding a number of other important benefits, including transportation allowances, certain dental benefits, and access to employment training are not appealable, even though such decisions significantly shape how social assistance is provided to and experienced by those reliant on it. Given the extremely low benefit levels in Ontario's two social assistance programs, particularly its Ontario Works program, these non-appealable benefits serve as crucial supplements to meagre basic benefits available through social assistance. See ODSPA, s 21 and OReg 222/98, ss 45.2, 57; OWA s 26 and OReg 134/98, ss 59, 68. 
challenge social assistance legislation. ${ }^{42}$ Social assistance recipients are thus unable to challenge a caseworker's decision denying benefits as being contrary to the Code at the SBT, even if the decision in question involves the small set of benefits that are appealable to the SBT. Yet caseworkers' decisions are precisely where discrimination can creep into the application of social assistance law and policy. ${ }^{43}$ Together, the jurisdictional limits in social assistance legislation and SBT policy confine rights enforcement so narrowly that it is rarely a useful strategy. ${ }^{44}$

Of course, a prudent and fully informed human rights claimant could address these gaps by filing concurrent claims at the HRTO and SBT so as to increase the chances of her claims being heard and resolved. ${ }^{45}$ Such a strategy does not, however, mitigate the risk that both tribunals might dismiss her human rights claims without addressing their substance. ${ }^{46}$ More importantly, this kind of strategic litigation is simply unrealistic for many who rely on social assistance and, arguably, for most nonlawyers. ${ }^{47}$ Jurisdictional intricacies such as the ones described above combine with other barriers to rights enforcement to place the promises of human rights out of reach for many who depend on government benefits. ${ }^{48}$

\section{Onerous Legal Tests}

The test for establishing human rights violations in government benefits programs is a third impediment to rights enforcement's effectiveness, as it has evolved to impose a heavy burden of proof on claimants.

In Ontario, the legal test for Code-based discrimination has evolved so that claimants must now meet the more onerous Charter test for equality rights violations, despite the important differences between the conventional tests for establishing unlawful discrimination under human rights codes and the Charter. Because of their ameliorative goals, human rights codes are typically structured to place a heavier onus on respondents to prove that, once a claimant has demonstrated the existence of differential

42 Practice Direction 6, supra note 35.

43 Bruce Feldthusen \& Nathalie des Rosiers, "Discretion in Social Assistance Legislation" (1992) 8 J L \& Soc Pol'y 204; Michael Adler \& Stewart Asquith, eds, Discretion and Welfare (London: Heinemann, 1981).

44 It is troubling that so many human rights claims raised to the SBT following Tranchemontagne have been dismissed for lack of jurisdiction. Of the 15 appeals involving human rights claims that have reached a hearing on the Code arguments raised, only one has successfully established a Code violation:the appeal of Tranchemontagne and Werbeski. A significant number of appeals have not been heard by the SBT because they do not challenge particular provisions of social assistance legislation: see Raso, supra note 33.

45 Cornish, Faraday \& Pickel, supra note 17 at 157-58.

46 For instance, see Volnyansky $v$ Peel (Regional Municipality) 2014 CanLII 1716 (HRTO), where the HRTO found that the applicant's human rights claim, which challenged her improper treatment as a single person despite the fact that she had three dependent children, was appropriately dealt with by the SBT. However, it is unlikely that the SBT addressed Ms. Volnyasnky's human rights claim given the SBT's Practice Direction 6, supra note 35, and because it was raised at a late stage before the SBT.

47 Joan M Gilmour, "Retrenchment not Reform: Using Law and Policy to Restrict the Entitlement of Women with Disabilities to Social Assistance" in Shelley Gavigan \& Dorothy Chunn, eds, The Legal Tender of Gender: Welfare, Law and the Regulation of Women's Poverty (Oxford, Portland: Hart Publishing, 2010) 189 at 204; the low uptake of appeals by marginalized individuals is examined by Albert Currie, "The Legal Problems of Everyday Life" in Rebecca L Sandefur, ed, Access to Justice (Bingley, UK: Emerald/JAI Press, 2009) 1.

48 This phenomenon is not new. See, for instance, William H Simon, "The Rule of Law and the Two Realms of Welfare Administration" (1990) 56 Brook L Rev 777. 
treatment connected to a code-protected ground, such treatment nonetheless fits within a statutory exemption. $^{49}$ In this way, codes frame prima facie discrimination as unlawful, subject to a statutory provision exempting the discriminatory conduct. This balancing between claimant and respondent onuses is reflected in early case law establishing the test for proving discrimination under human rights codes. $^{50}$ By contrast, the legal test for proving a violation of one's equality rights under the Charter has evolved so that it is now quite difficult for claimants to satisfy. ${ }^{51}$ Despite recent restatements of the Charter test, it appears that claimants must still demonstrate that a government program has unjustifiably or arbitrarily treated them differently and that this treatment is connected to prejudice or stereotyping. ${ }^{52}$

As it grew more difficult and costly to bring successful equality claims using the Charter, strategic rights challenges to government benefits programs were increasingly brought under human rights codes. $^{53}$ In response, government respondents successfully advocated that the more onerous Charter test should apply in Code claims that involve the delivery of government benefits programs. Although the recent Supreme Court of Canada decision in Moore suggests a return to the conventional test for proving Code violations, ${ }^{54}$ recent tribunal decisions in Ontario suggest that the Charter test still applies for Code challenges to government benefits and services. ${ }^{55}$ After tracing why this is the case, I will explain how the Charter test acts as a third barrier to rights enforcement.

Two years before Moore was decided, the Ontario Court of Appeal confirmed that the Charter test for proving a violation of one's equality rights applied in Code claims challenging the administration of

49 Denise Réaume, "Defending the Human Rights Codes from the Charter" (2012) 9 J L \& Equality 67.

50 Ontario Human Rights Commission and O'Malley v Simpsons-Sears, [1985] 2 SCR 536, in which Justice McIntyre set out the test for prima facie discrimination at para 28: "A prima facie case ... is one which covers the allegations made and which, if they are believed, is complete and sufficient to justify a verdict in the complainant's favour in the absence of an answer from the respondent."

51 A 2004 study of Supreme Court of Canada decisions on s 15 equality claims noted that the success rate of equality rights litigants was significantly lower as compared to Charter claimants generally: Bruce Ryder, Cidalia C Faria \& Emily Lawrence, "What's Law Good For? An Empirical Overview of Charter Equality Rights Decisions" (2004) 24 SCLR (2d) 103. A more recent study notes that the SCC is granting leave to appeal to relatively few s. 15 Charter challenges: Bruce Ryder \& Taufiq Hashmani, "Managing Charter Equality Rights: The Supreme Court of Canada's Disposition of Leave to Appeal Applications in Section 15 Cases, 1989-2010” (2010) 51 SCLR (2d) 505.

52 In $R v$ Kapp, 2008 SCC 41, [2008] 2 SCR 483 [Kapp], the SCC confirmed the need for equality rights claimants to prove differential treatment connected to stereotyping or prejudice. This requirement seems to have been relaxed by the more recent decision in Québec (Attorney General) v A, 2013 SCC 5, [2013] 1 SCR 61 [Qc v A], yet prejudice and stereotyping may persist as part of the requirement that differential treatment be arbitrary.

53 Mummé, supra note 22.

54 Moore v British Columbia (Minister of Education), 2012 SCC 61, [2012] 3 SCR 360 [Moore]. Reviewing Moore in detail is beyond the scope of this article. For a thought-provoking set of articles on this decision, see (2013) $10 \mathrm{~J}$ L \& Equality, including Joanna Birenbaum \& Kelly-Gallagher Mackay, "From Equal Access to Individual Exit: The Invisibility of Systemic Discrimination in Moore" (2013) 10 J L \& Equality 93.

55 My argument here is based on relevant HRTO and appellate court decisions involving government benefits and addressing the question of the appropriate test for discrimination. Because the SBT has only released one decision on the merits of a Code-based claim, and because that decision resulted in the leading Ontario Court of Appeal case on the issue (Ontario (Disability Support Program) v Tranchemontagne, 2010 ONCA 593 [Tranchemontagne 2]), my argument assumes that the SBT will, in any future decisions on human rights claims, follow the HRTO's lead on the appropriate test to apply when it decides allegations of unlawful discrimination under the Code. 
government benefits. ${ }^{56}$ Administrative tribunal decisions released following Moore, however, confirm that the Charter test remains authoritative in Ontario. ${ }^{57}$ In Rudkins, for instance, the HRTO read Moore as not displacing the requirement that claimants meet the Charter test for discrimination in government services cases. ${ }^{58}$ The HRTO noted that Moore did not explicitly rule out use of the Charter test in discrimination claims, and that Moore continued to link discrimination with arbitrary treatment. ${ }^{59}$ The core elements of the discrimination test under the Code have thus been interpreted as being in harmony with the requirements of the Charter test for equality rights violations, and the burden on rights claimants to prove substantive discrimination has been read to require that claimants prove arbitrary treatment based on prejudice or stereotyping. Other decisions at both the HRTO and the SBT confirm this trend. ${ }^{60}$

Because of the continued influence of the Charter test, claimants must meet a more onerous burden of proof earlier on, making it more difficult to successfully establish prima facie discrimination in government benefits programs. Proving Charter equality claims, especially those that target redistributive government benefits, has always been difficult. ${ }^{61}$ However, the Charter test has evolved to become more onerous for all claimants because of the continued role that arbitrariness, prejudice and stereotyping play in evaluating whether a claimant has proved differential treatment amounting to a Charter violation. ${ }^{62}$ Connecting differential treatment to arbitrary prejudice or stereotyping is tricky.

56 This shift was confirmed by the Ontario Court of Appeal in Tranchemontagne 2, ibid, in which the Court held that the SBT must apply the Charter test for equality rights violations when considering Code claims.

57 Most recently, the HRTO confirmed that the Charter test applies to challenges involving government services in Peart $v$ Ontario (Community Safety and Correctional Services), 2014 CanLII 611 (HRTO) [Peart]. The SBT has also applied the Charter test in Code-based claims: SBT File No 0904-03555, 2013 CanLII 1535 (ONSBT).

58 The HRTO decision that addresses this issue most directly is Rudkins v Durham Catholic District School Board, 2014 HRTO 1098 (CanLII) [Rudkins].

59 See Moore, supra note 59 at para 33 where Justice Abella, writing for the Court, sets out the test for discrimination, but also see paras 26, 32, 34, 26 and 59-61 where Justice Abella reaffirms the role that arbitrariness and unjustified denials of benefits play in the legal test for discrimination.

60 Peart, supra note 62, Rudkins, supra note 63 at para 38. One reason the HRTO appears to incorporate prejudice and stereotyping into the Code test for discrimination even post-Moore is the wording of the OHRC's Policy and Guidelines on Disability and the Duty to Accommodate" (December 2009), online: Ontario Human Rights Commission $<$ http://www.ohrc.on.ca/en/policy-and-guidelines-disability-and-duty-accommodate $>$. The HRTO has used this policy in other decisions to explain how Moore can be read harmoniously with the Charter test for discrimination affirmed in Tranchemontagne 2: King v Ontario (Community and Social Services), 2015 HRTO 307 (CanLII) at paras 18, 24

61 See for instance Gosselin, supra note 20; Tanudjaja v Canada (Attorney General), 2013 ONSC 5410, aff'd 2014 ONCA 852 , leave to appeal to SCC refused, 36283 (25 June 2015). See also Judith Keene, "The Supreme Court, the Law Decision, and Social Programs: The Substantive Equality Deficit" in Fay Faraday, Margaret Denike \& M Kate Stephenson, eds, Making Equality Rights Real: Securing Substantive Equality Under the Charter (Toronto: Irwin Law, 2006) 345.

62 The reframing of the legal test for a violation of s 15 of the Charter occurred in Kapp, supra note 57 . While the requirement for linking unequal treatment with prejudice or stereotyping may have been lessened somewhat by Justice Abella's decision $Q c v$ A, supra note 57, it remains uncertain what authority her judgment will have given how the Court divided on the issue of the appropriate test for s 15 equality claims and because of Justice Abella's continued reference to arbitrariness in her discussion of unlawful unequal treatment. Jennifer Koshan provides an excellent analysis of why Moore may not signal a return to a simpler test for establishing prima facie discrimination under human rights codes in "Under the Influence: Discrimination under Human Rights Legislation and Section 15 of the Charter" (2014) 3 Can J Human Rights 115, especially at 128-32. 
Judges and tribunal members may be incapable of recognizing the existence of such stereotyping in discrimination cases because claimants who are farthest from the norm and most likely to be the subject of stereotype may appear "most genuinely different" and thus deserving of unequal treatment. ${ }^{63}$ Reviewing decision-makers may therefore be unable to recognize that a claimant's experience of discrimination involves stereotyping, as it may appear to be rational treatment based on actual difference.

Practically speaking, the requirement that claimants must meet the Charter test for equality rights violations to establish a prima facie case of discrimination under the Code is a tall and early hurdle for rights claims involving government benefits programs. Claimants who launch such challenges must now produce more evidence at earlier stages in their administrative tribunal hearings, shifting the burden of proof from respondents to claimants in what was originally intended to be an accessible, claimantfriendly process. Combined with the cost, delay, and complex jurisdictional issues that arise when rights claims are made against government benefits programs, this more onerous test makes it exceedingly difficult for claimants to successfully prove that they have experienced a Code violation and obtain relief.

\section{Power Disparities}

The barriers to rights enforcement reviewed so far are commonly identified as across-the-board obstacles to litigation. In addition, rights claimants seeking to transform government benefits are faced with the structural inequality that exists between individual claimants and government respondents. Even if the first three barriers to rights enforcement could be minimized - by making dispute resolution more efficient, broadening administrative decision-makers' authority to determine rights issues, or simplifying legal tests - the unequal relationship between claimants and the agencies that deliver benefits such as social assistance would remain a significant obstacle to achieving institutional change. In the remainder of this section, I consider the relationship between rights claimants and government respondents as a fourth barrier to rights enforcement.

As a strategy for reforming government benefits programs, rights enforcement relies on the individual claims of those dependent on social assistance, who are themselves some of society's most marginalized members. ${ }^{64}$ However, the unequal relationship between social assistance recipients and program administrators leaves social assistance recipients both less likely to initiate human rights claims and, for those who do initiate claims, less able to ensure that their claims have a lasting impact on how social assistance is delivered. First, because social assistance recipients may be unlikely to initiate human rights claims, ${ }^{65}$ those who may be most in need of statutory human rights code protections, including persons with disabilities, newcomers, and sole-support mothers, are least able to benefit from them. Although they may perceive that their rights have been violated, few may reach a point where

63 Margot Young, "Unequal to the Task: 'Kapp'ing the Substantive Potential of Section 15" (2010) 50 SCLR (2d) 183 at 204-09.

64 See Brighter Prospects, supra note 9.

65 While an empirical analysis of the data on all rights claims involving social assistance brought to the HRTO and SBT is beyond the scope of this article, the limited numbers of social assistance recipients that have commenced rights claims at the SBT following Tranchemontagne suggests that rights claims form only a small proportion of appeals by social assistance recipients: Raso, supra note 33. 
they can name their experience as a legal problem and take action to enforce their rights. ${ }^{66}$ Social assistance recipients in particular may be so exhausted from navigating the intricate program rules, numerous application forms, and documentary requirements that are a condition of accessing a panoply of meagre benefits, ${ }^{67}$ and from the reality of poverty itself, that they may be practically unable to initiate formal rights claims. ${ }^{68}$ Alternatively, those who experience discriminatory treatment may not want to position themselves as victims, which a rights claim can implicitly symbolize. ${ }^{69}$ More importantly, some may not even realize that their treatment by social assistance administrators amounts to unlawful discrimination because caseworkers may not communicate the real reasons for their decisions to their clients. $^{70}$ All of these factors, taken together, make it unlikely that many social assistance recipients will launch rights-based claims to challenge how their benefits are (or are not) being delivered.

Second, the power disparity between those reliant on government benefits and those responsible for delivering such benefits can also make it incredibly difficult for individuals who do commence rights claims to ensure that their claims actually impact how benefits programs function. This challenge manifests itself in three ways: the pressures on claimants to settle their rights claims; the barriers they experience when implementing rights-enhancing remedies; and, the practical limits to claimants engaging in further litigation when government agencies curtail the application of rights-enhancing remedies.

The vulnerability of social assistance recipients can make them more inclined to settle their claims rather than pursue them at a hearing. ${ }^{71}$ The administrative actors who are typically respondents to human rights claims are experienced "repeat players", to use Marc Galanter's term, that are more invested in the state of legal rules and less in the outcome of individual cases. Because of this, respondents whose programs are challenged by human rights claims can pursue those cases that they

66 See William LF Felstiner, Richard L Abel \& Austin Sarat, "The Emergence and Transformation of Disputes: Naming, Blaming, Claiming...” (1980) 15:3 Law \& Soc'y Rev 631. The authors note that early stages of dispute transformation are significant as vulnerable individuals may not identify an injurious experience as one that can be "named" as a legal dispute. Thus, accessible justice solutions focused on increasing litigation may privilege those who are already socially advantaged and able to name their disputes, perpetuating inequality as a result.

67 See Dean Herd, Andrew Mitchell \& Ernie Lightman, "Rituals of Degradation: Administration as Policy in the Ontario Works Program” (2005) 39:1 Social Policy \& Administration 65.

68 This phenomenon, identified as "applicant fatigue", is explored in David Cowan \& Simon Halliday, The Appeal of Internal Review: Law, Administrative Justice and the (non-)Emergence of Disputes (Oxford: Hart Publishing, 2003) at 139-40. See also Gilmour, supra note 19, in the context of disability support appeals. It is important to note, however, that this phenomenon may not exist in all situations where unequal power dynamics exist between rights claimants and those who administer government programs. For a recent study exploring the proliferation of rights claims in the form of prisoners grievances in California prisons, see Kitty Calavita \& Valerie Jenness, Appealing to Justice: Prisoner Grievances, Rights, and Carceral Logic (Oakland: University of California Press, 2015).

69 Kristen Bumiller, The Civil Rights Society: The Social Construction of Victims (Baltimore: John Hopkins University Press, 1988).

70 For instance, both Werbeski and Tranchemontagne were unaware that they were initially denied disability benefits because of their alcohol addiction, as the decision letters originally provided to both men stated simply that they were found to not be disabled within the meaning of the ODSPA. This fact was not revealed to both men until they received copies of their administrative records at their SBT hearings, at which point they amended their SBT appeals to include a human rights claim: Tranchemontagne, supra note 10 at para 22.

71 Joel F Handler, "Discretion in Social Welfare: The Uneasy Position of the Rule of Law" (1983) 92:7 Yale LJ 1270

[Handler, "Discretion in Social Welfare"]. 
expect will result in a beneficial precedent or rule change and settle those that will not. ${ }^{72}$ By contrast, claimants who rely on government benefits are usually infrequent litigants, or "one-shotters", whose human rights claims are too costly to pursue relative to their resources. As such, social assistance recipients may forego the chance to enforce their rights in a way that would benefit others for the opportunity to settle their own claims early on, especially if settlement involves accessing much-needed benefits. ${ }^{73}$ The unequal position of rights claimants and government respondents can thus produce incentives for settlement that ultimately reduce the likelihood of an individual rights claim impacting how social assistance benefits are delivered to others. ${ }^{74}$

Further, the few claimants who are awarded systemic remedies as part of a settlement agreement or tribunal order may be unable to implement these remedies so as to achieve wider institutional change. Instead, "bureaucratic contingencies" and the power disparities between rights claimants and benefitdelivering agencies can limit the chance that successful litigation will lead to tangible and lasting institutional reform. ${ }^{75}$ Rule changes achieved through litigation are often symbolic, particularly because government respondents are practically free to choose how they will implement tribunal-ordered human rights remedies. ${ }^{76}$ Administrative agencies responsible for delivering government benefits are wellequipped with tools that can limit the reach of rights remedies, such as the ability to craft new policies or read down tribunal orders so as to restrict their impact to a single set of facts. ${ }^{77}$

For instance, as noted earlier, a body such as the SBT may use its policy-making powers to narrow the impact of a court-ordered change to its administrative practice. Following Tranchemontagne, the SBT's policy makers interpreted the Court's decision as only requiring the SBT to hear those human rights challenges that targeted specific social assistance legislation provisions. ${ }^{78}$ This reads the decision

72 Marc Galanter, "Justice in Many Rooms" in Mauro Cappelletti, ed., Access to Justice and the Welfare State (Alphen ann den Rijn: Sijthoff, 1981) 147 at 160, 167-69; Marc Galanter, "Why the 'Haves' Come out Ahead: Speculations on the Limits of Legal Change" (1974) 9:1 Law \& Soc'y Rev 95 at 97 [Galanter, "Haves Come out Ahead"].

73 Galanter, "Haves Come out Ahead", ibid at 98-106. It should be noted that Galanter's observation here may be true in certain institutional contexts where individuals rely on a government benefit, such as social assistance, but less applicable in hyperlegal or "total legal institutions" where a state agency, such as a department of corrections, has excessive control over potential rights claimants: Calavita \& Jenness, supra note 74 at 182-83.

74 An additional complicating factor is the dearth of systemic remedies awarded in Code-based claims involving social assistance, which make it less likely that social assistance and similar programs can be transformed through settlements. Not only are remedies targeting systemic discrimination uncommon in HRTO decisions involving social assistance, as noted above in Part II, but the SBT's jurisdictional limits (which restrict the SBT to decisions on individual benefits eligibility) prohibit it from ordering broader program changes. The practical and legal limits on each tribunal's jurisdiction to award remedies in rights claims shape the scope of remedies that parties will seek in any settlement negotiations, giving reason to doubt that systemic remedies would be included in the settlement of an individual rights claim.

75 Joel F Handler, Social Movements and the Legal System: A Theory of Law Reform and Social Change (New York: Academic Press, 1978) at 13-14. See also Mark Tushnet, "The Critique of Rights" (1993) 47:1 SMU L Rev 23.

76 Galanter, "Haves Come out Ahead", supra note 78 at 114-24.

77 Litigation's limited ability to change administrative practices is examined by Simon Halliday, Judicial Review and Compliance with Administrative Law (Oxford, Portland: Hart Publishing, 2004). See also Jerry L Mashaw, Bureaucratic Justice: Managing Social Security Disability Claims (New Haven: Yale University Press, 1983); Marc Hertogh \& Simon Halliday, eds, Judicial Review and Bureaucratic Impact: International and Interdisciplinary Perspectives (Cambridge: Cambridge University Press, 2004).

78 Practice Direction 6, supra note 35. 
too narrowly, though, as it based the SBT's authority to consider the Code on its power to hear and determine questions of law. Presumably, the SBT must hear not only those rights claims challenging specific provisions of social assistance legislation, but also claims targeting how caseworkers and their supervisors interpret and apply such legislation. ${ }^{79}$ Despite its shaky legal foundation, it is not surprising that the SBT's policy on human rights claims has gone uncontested, though. It is unreasonable to expect that social assistance recipients are in a position to raise complex legal arguments based on the finer points of the SBT's jurisdiction. ${ }^{80}$

Finally, where rights claimants succeed in their Code-based challenges to government benefits programs, government respondents are well-positioned to engage in further litigation to secure a favourable rule change. This was indeed the case following Tranchemontagne, where the provincial ministry responsible for social assistance engaged in a new set of appeals to advocate for the application of the more onerous Charter test in Code-based challenges to public benefits programs. ${ }^{81}$ As we have seen, now those who seek to transform benefits programs through Code-based discrimination claims must meet the trickier Charter test for equality rights violations. This rule change favours government respondents, as it makes it more difficult for claimants to establish that social assistance benefits are being delivered in ways that are prima facie discriminatory. ${ }^{82}$ It is unrealistic to expect social assistance recipients to respond with a new set of rights claims, particularly given the dampening effect of other barriers to rights enforcement. For all of these reasons, then, rights enforcement's reliance on unequally situated parties to generate social and institutional change is itself an obstacle. When one party relies on the other for basic necessities, and the other party has considerable control over the environment in which benefits are delivered as well as the resources to engage in further litigation, there are good reasons to reconsider whether rights enforcement is the best strategy for change.

Law and social change scholars typically respond to the obstacles facing rights enforcement in two ways. The first response focuses on mitigating the barriers to rights enforcement, while the second maintains that rights enforcement is a valuable tool for social and political transformation despite its shortcomings. Those taking the former approach may acknowledge that the uneven balance of power between rights claimants and government respondents can limit the effectiveness of rights litigation, but they nevertheless propose to minimize this danger by improving access to formal legal institutions and processes. Some argue in favour of enabling rights claimants to better access legal representation, particularly lawyers who are skilled in social justice advocacy. ${ }^{83}$ The teaming up of one-shotters and

79 Indeed, given the majority's decision about whether the SBT could decline jurisdiction to hear Tranchemontagne and Werbeski's rights claim, the SBT's use of its policy-making powers to purportedly narrow its jurisdiction to only those Code challenges aimed at discrete legislative provisions is suspect: Tranchemontagne, supra note 10 at paras 43-52.

80 In addition, it may be nearly impossible to challenge a tribunal policy using superior court litigation, as courts are generally loath to interfere on policy matters. Lorne Sossin examines the difficulties inherent in challenging administrative policies in the context of Charter litigation in "Discretion Unbound: Reconciling the Charter and Soft Law" (2003) 45:4 Canadian Public Administration 465 [Sossin, "Discretion Unbound"].

81 See Tranchemontagne 2, supra note 60.

82 Lesli Bisgould, "Twists and Turns and Seventeen Volumes of Evidence, or How Procedural Developments Might Have Influenced Substantive Human Rights Law" (2012) 9 J L \& Equality 4.

83 Galanter suggests that if claimants work together with experienced public interest lawyers, their position can more closely approximate that of other repeat players; "Haves Come Out Ahead," supra note 78 at 135-44. However, Richard Abel questions this claim, noting that litigation is itself a conservative institution and thus any substantially progressive 
public interest lawyers, some think, not only levels out the litigation experience of rights claimants and repeat players but also ensures that claimants have more influence in how government programs operate. $^{84}$ Others propose that the formal legal processes characteristic of litigation are better at ensuring that rights claimants are treated fairly as compared to the more flexible procedures available in informal dispute resolution settings. ${ }^{85}$

Mitigation arguments fail to address the dilemma underlying much writing on access to justice: namely, that improved access to legal representation and formal decision-making processes does not make litigation better at achieving deep institutional or social change. In fact, participating in formal litigation may divert attention and energy away from other means of challenging fundamental and entrenched inequities. ${ }^{86}$ Human rights codes, in particular, aspire to a range of intricate social and institutional changes. Achieving these changes is an elusive task, whether or not one is represented by a lawyer or participates in a court or tribunal proceeding. Though legal representation may help a rights claimant translate her experience into language familiar to a court or tribunal, and a skilled legal professional may make a claimant feel that she is not alone in her challenge to a powerful government agency, motivating her to see her claim through rather than settle early on, the relationship between claimants who rely on public benefits and government agencies empowered to design and deliver such benefits is skewed in ways that inhibit fundamental institutional change. Claimants often remain dependent on the agency whose actions they challenge both during and after litigation, which may entice them to settle their cases more quickly or not pursue more transformative remedies for fear of retribution by those delivering social assistance. ${ }^{87}$ Likewise, improved access to legal representatives, courts, and tribunals does not seem to correlate to one's ability to ensure that the remedies she obtains are successfully implemented. On the contrary, access to lawyers can magnify the barriers to rights enforcement, embroiling claimants in lengthy legal proceedings that bear significant emotional and financial costs and diverting attention and resources from alternative strategies for realizing rights. ${ }^{88}$

As for the transformative response to the barriers facing rights enforcement, it rests on the belief that even unsuccessful rights claims can inspire long-term institutional change. This position sees law as a medium for change rather than a hegemonic system and litigation as a social and political tool. Scholars in this camp note that the process of making rights claims can change how claimants view themselves, and that even unsuccessful claims can popularize alternative views on complex phenomena such as structural inequality and social exclusion. ${ }^{89}$ Legal consciousness scholars, for instance, note that formal

legal change sought in courts must be preceded by equally progressive social change: "Socializing the Legal Profession: Can Redistributing Lawyers' Services Achieve Social Justice" (1979) 1 Law \& Pol'y 5.

84 See Galanter, "Haves Come out Ahead," ibid at 103. See also Beth Harris, "Representing Homeless Families: Repeat Player Implementation Strategies" (1999) 33:4 Law \& Soc’y Rev 911

85 Richard Delgado et al, "Fairness and Formality: Minimizing the Risk of Prejudice in Alternative Dispute Resolution" (1985) 1985:6 Wis L Rev 1359.

86 Bumiller, supra note 75; Carol Smart, Feminism and the Power of Law (London: Routledge, 1989). For a more recent critique, see also Butler, supra note 7.

87 Joel F Handler, "Continuing Relationships and the Administrative Process: Social Welfare" (1985) 1985:3 Wis L Rev 687 at 690.

88 Langer, supra note 2, acknowledges this phenomenon in relation to the effect of lawyers in the former Ontario Human Rights Commission.

89 See Stuart Scheingold's discussion in The Politics of Rights: Lawyers, Public Policy, and Political Change (New Haven: Yale University Press, 1974), particularly Ch 9 at 131-48. 
legal claims can help marginalized people "stan[d] against the law" and thus subvert its power, even temporarily. $^{90}$ By making legal claims and harnessing lawyers' expertise, those who rely on social assistance can improve their sense of agency as they assert their needs and challenge the unfairness of social assistance programs that are supposed to help those in need but which often fail to do so. ${ }^{91}$ Others note that rights claims can raise the expectations of those who experience rights violations and inspire them to work towards equality-enhancing social and political change. ${ }^{92}$ When viewing rights litigation as a means of changing public opinion, some see even failed rights claims as catalysts for shifting widely-held beliefs about marginalized people, and those who favour the strategic mobilization of rights language may use failed litigation as a basis on which to advocate for change at other levels of government. ${ }^{93}$ According to this view, even claims that are dismissed by tribunals and courts can inspire efforts to realize rights through other means. ${ }^{94}$

Although unsuccessful litigation may catalyze efforts to realize rights through other means, rights enforcement alone is unlikely to achieve the deeper ameliorative goals underpinning human rights codes. Rights may remain strategically useful as a building block for social and institutional change, and legal rights may retain their normative pull. Yet, too often the turn to rights leads down a road where litigation is the endpoint rather than one stop on the path to a more transformative destination. Because litigation brings with it significant costs - funds, energy, social and political capital - rights enforcement strategies can risk depleting the social, political, and financial resources that individuals and social justice advocacy organizations must draw on to engage in other methods of accomplishing the ameliorative goals of human rights codes. ${ }^{95}$ Litigation's tendency to dominate the list of options for realizing rights is therefore problematic.

Realizing rights thus requires that we explore alternative strategies for achieving the promise of human rights codes, strategies focused on redistributing power between those reliant on government benefits and the agencies that provide such benefits. This project is as much social and political as it is legal. It may seem useful to engage the help of legal professionals to ensure that the remedies achieved through rights enforcement mechanisms permeate administrative agencies, ${ }^{96}$ but it is practically impossible to implement tribunal or court orders if they are met with significant institutional resistance. ${ }^{97}$ Instead, efforts must focus within administrative agencies, at the program designers, policy writers, managers, and caseworkers who influence how government benefits and services are delivered. This proposal requires shifting social and institutional attitudes to ensure that social assistance recipients

90 Patricia Ewick \& Susan Silbey, The Common Place of Law: Stories From Everyday Life (Chicago: University of Chicago Press, 1998) at 165.

91 Austin Sarat, "The Law is All Over': Power, Resistance and the Legal Consciousness of the Welfare Poor” (1990) 2:2 Yale JL \& Human 343.

92 Michael W McCann, Rights at Work: Pay Equity Reform and the Politics of Legal Mobilization (Chicago: University of Chicago Press, 1994) at 280; Francesca Polletta, "The Structural Context of Novel Rights Claims: Southern Civil Rights Organizing, 1961-1966" (2000) 34:2 Law \& Soc'y Rev 367.

93 Scheingold, supra note 95. This discussion is taken up in Tracey Heffernan, Fay Faraday \& Peter Rosenthal, "Fighting for the Right to Housing in Canada" (2015) 24 J L \& Soc Pol'y 10 at 14-15

94 Fay Faraday, "Dealing with Sexual Harassment in the Workplace: The Promise and Limitation of Human Rights Discourse" (1994) 32:1 Osgoode Hall LJ 33 at 35-40.

95 Bumiller, supra note 75.

96 Galanter, "Haves Come Out Ahead," supra note 78.

97 Scheingold, supra note 95. 
are involved in the discretionary decisions that affect their benefits and to foster participatory relationships supportive of human rights values. ${ }^{98}$ To be clear, it is not that rights enforcement must be abandoned entirely. Rights challenges can illuminate unjust practices that call out for reform and remain important tools for political mobilization. ${ }^{99}$ However, substantial energy is presently directed towards rights enforcement efforts to the detriment of a slower, less glamourous, but arguably more effective project of integrating rights values into the fabric of government benefits programs. The balance of this article, accordingly, offers some thoughts about how a rights integration approach might be used to guide the delivery of social assistance in Ontario.

\section{INTEGRATING RIGHTS AND ADMINISTRATIVE DISCRETION}

Proposing that human rights values be integrated into the discretionary decisions of agencies that deliver government benefits is more than a theoretical experiment. There are legal and practical reasons for focusing on the everyday decisions which shape the administration of programs such as social assistance. Experimenting with alternative mechanisms for realizing rights can help government agencies meet their legal obligations as providers of public goods and services to deliver benefits in harmony with the ameliorative goals of human rights codes. These codes are foundational, quasiconstitutional laws with primacy over the laws regulating social assistance. ${ }^{100}$ As such, both front-line workers and policy-writers are arguably already required to interpret and apply the legal framework governing social assistance in accordance with the values underlying human rights codes so as to support and respect the dignity and worth of those in need of assistance. ${ }^{101}$ The practical reasons supporting a rights integration approach are connected to the insights from law and social change scholarship. Because of rights enforcement's shortcomings, reviewed in Part III, it is essential that scholars investigate alternatives for achieving the social and institutional transformations that human rights codes inspire. The remainder of this article explores how administrative discretion offers a rich set of opportunities and challenges for rights integration.

As I will demonstrate below, not only is administrative discretion endemic in programs such as social assistance, allowing for great flexibility in program design and benefit delivery, but it is precisely through the exercise of discretion that discrimination can influence the distribution of government benefits. The perceived dangers that discretion poses are conventionally met with calls to structure and confine the decisions of front-line administrators through the use of rules, policies and other regulatory

98 Joel F Handler, Down From Bureaucracy: The Ambiguity of Privatization and Empowerment (Princeton: Princeton University Press, 1996).

99 Joel B Grossman \& Austin Sarat, “Access to Justice and the Limits of Law” (1981) 3:2 Law \& Pol'y 125 at 137.

100 See Tranchemontagne, supra note 10 at paras 33-42 where the majority discusses the Code's quasi-constitutional status and how it is to be read together with other provincial legislation. See also the Code, s 47(2) which confirms the Code's primacy over other provincial legislation.

101 It is useful to revisit the aspirational goals set out in the Ontario Code's preamble, which reads in part "[I]t is public policy in Ontario to recognize the dignity and worth of every person and to provide for equal rights and opportunities without discrimination that is contrary to law, and having as its aim the creation of a climate of understanding and mutual respect for the dignity and worth of each person so that each person feels a part of the community and able to contribute fully to the development and well-being of the Province". 
technologies. ${ }^{102}$ Yet, discretion as a phenomenon raises complex questions about the power dynamics at play between administrative decision-makers and those affected by their decisions. ${ }^{103}$ To explore how rights integration could be used to reshape the relationship between those reliant on social assistance and those who administer such programs, this section first describes how discretion functions in both individual and institutional decisions. It then considers discretion's pervasiveness by examining the phenomena of polycentric decisions and rule interpretation. Finally, it closes with some thoughts about how rights integration might act as a counterpart to rights enforcement, proposing a pluralist argument in favour of rights-infused discretion.

\section{A. Individual and Institutional Discretion}

Discretion poses a dilemma for administrative law scholars. Commonly viewed as existing in opposition to law, discretion is often framed as something that can lead to arbitrariness in administrative decisions and, thus, as a threat to the rule of law. ${ }^{104}$ In response, administrative law literature often advocates controlling and structuring discretion through some combination of rules and external oversight. ${ }^{105}$ Discretion is, however, integral to and inseparable from administrative decision-making. ${ }^{106}$ Socio-legal studies of administrative discretion challenge the artificiality of the discretion-law binary, ${ }^{107}$ demonstrating how attempts to rein in discretion can lead to its proliferation, ${ }^{108}$ and how discretion is always exercised in relation to rules and broader norms. ${ }^{109}$ "Discretion" includes a wide variety of decisions in which administrative actors, be they policy-makers, managers, or caseworker, are presented with choices between options. In approaching discretion this way, I do not propose that these choices exist autonomously in a space outside of law, but rather that discretionary decisions are a distinct sphere of legal action ${ }^{110}$ as decision-makers use their discretion to interpret and apply broad and sometimes contradictory laws and policies to a particular set of facts. ${ }^{111}$ Despite the number of rules, policies, and

102 Anna C Pratt, "Dunking the Doughnut: Discretionary Power, Law, and the Administration of the Canadian Immigration Act" (1999) 8:2 Soc \& Leg Stud 199.

103 Robert Baldwin \& Keith Hawkins, "Discretionary Justice: Davis Reconsidered" (1984) 1 Public L 570.

104 Geneviève Cartier, "Administrative Discretion: Between Exercising Power and Conducting Dialogue" in Collen M Flood \& Lorne Sossin, eds, Administrative Law in Context, 2nd ed (Toronto: Emond Montgomery, 2013) 381 at 385-88.

105 The classic example of this is Davis, who called for the confining, structuring, and checking of administrative discretion with an array of rules, policies and administrative review mechanisms: Davis, supra note 12.

106 Joel F Handler, The Conditions of Discretion: Autonomy, Community, Bureaucracy (New York: Russell Sage Foundation, 1986) at 169 [Handler, Conditions of Discretion]. See also Brodkin, supra note 12.

107 For an early account, see Nicola Lacey, "The Jurisprudence of Discretion: Escaping the Legal Paradigm" in Keith Hawkins, ed, The Uses of Discretion (Oxford: Clarendon Press, 1992) 361. Vic Satzewich traces how discretion is shaped by influences at micro, macro and meso levels, including by laws, policies, administrative cultures and social norms: "Visa Officers as Gatekeepers of a State's Borders: The Social Determinants of Discretion in Spousal Sponsorship Cases in Canada" (2014) 40:9 J Ethnic Migration Studies 1450.

108 John Braithwaite \& Valerie Braithwaite, "The Politics of Legalism: Rules versus Standards in Nursing-Home Regulation" (1995) 4 Soc \& Leg Stud 307.

109 Keith Hawkins, "The Use of Legal Discretion: Perspectives from Law and Social Science" in Keith Hawkins, ed, The Uses of Discretion (Oxford: Clarendon Press, 1992) 1.

110 Denis J Galligan, Discretionary Powers: A Legal Study of Official Discretion (Oxford: Clarendon Press, 1986).

111 In many ways, this framing of discretion mirrors notions of judgment. While expanding on this aspect of how I frame discretion is beyond the scope of this article, it is important to note the parallels between the complexity of decision- 
other regulatory mechanisms created to restrict it, discretion continues to flourish at two interrelated places within administrative agencies: in individualized decisions; and, in the broader decisions that shape the design and function of administrative institutions. ${ }^{12}$

Discretion operates at the micro, or individual, level in decisions regarding the rights and entitlements of specific individuals, such as those applying for welfare or disability benefits. Individual discretion is often exercised by front-line decision-makers, such as caseworkers and their supervisors, who use an array of social assistance legislation, policies, and regulatory tools (forms, checklists, case management software) to determine whether an individual is eligible for social assistance benefits. Individual discretion can include positive action, as in the choice to help a social assistance applicant obtain a spot in a job training or rehabilitation program, as well as inaction, such as a caseworker's choice to not advise a client suffering from a chronic health condition about the special diet allowance for which she may qualify. ${ }^{113}$ Individual discretion also encompasses procedural decisions, such as the order and timing of a caseworker's questions during an in-person interview assessing an applicant's eligibility for social assistance, and interpretive acts, such as which facts a caseworker will treat as important or relevant for determining the benefits and employment supports that would be most useful to a particular client. ${ }^{114}$. As noted earlier, some individual discretionary decisions may be reviewable by outside tribunals, such as the HRTO or SBT, while others may not, depending on the design of the administrative scheme in question, the breadth of its appeal rights, and how widely tribunals interpret their own jurisdiction. While individual discretion can be used to favour some social assistance recipients and disadvantage others, it also provides an opening through which the broad principles underlying human rights codes, such as fairness and respect, can shape routine administrative decisions. ${ }^{115}$

Administrative discretion also exists at a second macro, or institutional, level where program design decisions are made. This institutional discretion includes the discretion that policy makers use when creating the rules, policies and other tools that flesh out social assistance legislation. ${ }^{116}$ These may include directives with criteria designed to assist caseworkers in their benefit eligibility decisions, but can also include broader policy decisions affecting service accessibility, such as where offices are located, how early or late they are open, how many appointments are required before an eligibility

making that administrative actors are tasked with and decisions that are associated with judges, if only to unsettle the myth of front-line workers as paper-pushers and deskilled bureaucrats.

112 In this way, discretion is both local and dispersed, located across a range of managers, program designers and front-line workers within individual social assistance offices, in policy branches of provincial ministries responsible for social assistance, and across the many partner agencies who provide employment training and other supportive services that together comprise social assistance benefits: Pratt, supra note 108 at 218.

113 Keith Hawkins, Law as a Last Resort: Prosecutorial Decision Making in a Regulatory Agency (Oxford: Oxford University Press, 2002). For an exploration of how individual discretion can shape the interpretation and application of the legal framework governing social housing in Britain, see Simon Halliday, "Institutional Racism in Bureaucratic Decision-Making: A Case Study in the Administration of Homelessness Law” (2000) 27:3 JL \& Soc'y 449.

114 Baldwin \& Hawkins, supra note 109 at 583-84.

115 For instance, Kelly Hannah-Moffat, Paula Maurutto and Sarah Turnbull show how front-line decision-makers may use their discretion to soften the perceived discriminatory effects of regulatory tools, such as standardized risk assessment forms in probationary decision-making: "Negotiated Risk: Actuarial Illusions and Risk in Probation" (2009) 24:3 Can J Law \& Soc'y 391.

116 Galligan notes that policy-making is at the heart of administrative discretion, supra note 116 at 110. 
determination is made, and whether clients are greeted promptly and courteously when they seek assistance. ${ }^{117}$ As with individual discretion, institutional discretion also operates when administrative decision-makers fail to act, such as when more caseworkers are not hired in response to growing caseloads, or when rules and policies are not updated to accommodate the diverse population applying for social assistance. Institutional discretion can bureaucratically disentitle those in need of social assistance if it effectively discourages individuals from applying for benefits to which they are legally entitled. ${ }^{118}$ This phenomenon is particularly prevalent in programs such as social assistance, where increasing numbers of forms, application steps, and ongoing documentation requirements can make it quite difficult for individuals to successfully apply for welfare and disability benefits for which they qualify. ${ }^{119}$ Institutional discretion is frequently not scrutinized because administrative and human rights law doctrines often exclude such decisions from review. ${ }^{120}$ Nonetheless, institutional discretion can narrow or broaden how caseworkers exercise individual discretion and thus significantly shape individuals' experience of administrative agencies and access to government benefits. Institutional discretion allows for a certain creative freedom in designing social assistance policy, forms, and the offices in which benefits are delivered, and it can substantially shape individual discretion. Consequently, institutional discretion is a key target for rights integration.

Of course, there may be cases that blur the distinction between these two modes of discretion. For instance, a decision to increase social assistance rates affects the individual rights of all those who receive social assistance, yet it is also a broad policy decision. Similarly, the design of application forms and case management software can affect the order in which an individual caseworker questions a social assistance applicant which, if the applicant is left feeling alienated or frustrated, may affect whether she successfully provides all of the information necessary to establish her eligibility for benefits. By distinguishing between individual and institutional discretion, my aim is not to create watertight analytical categories. Rather, I wish to draw attention to the broad decision-making power available to and regularly exercised by a variety of administrative actors, including front-line workers, managers, and policy-writers, and the range of discretionary decisions that shape how social assistance is delivered. Functioning together, individual and institutional discretion shape how social assistance law is experienced by those who rely on government benefits to meet their basic needs.

117 See, for instance, Matthew Diller, "The Revolution in Welfare Administration: Rules, Discretion and Entrepreneurial | Government" (2000) 75:5 NYU L Rev 1121 at 1131; see also Laura Pottie \& Lorne Sossin, "Demystifying the Boundaries of Public Law: Policy, Discretion, and Social Welfare" (2005) 38:1 UBC L Rev 147

118 Michael Lipsky, "Bureaucratic Disentitlement in Social Welfare Programs" (1984) 58:1 Social Service Rev 3.

119 Lorne Sossin, "Boldly Going Where No Law Has Gone Before: Call Centres, Intake Scripts, Database Fields, and Discretionary Justice in Social Assistance" (2004) 42:3 Osgoode Hall LJ 363.

120 Administrative law, developed largely through judicial review decisions, classifies institutional discretion as an "administrative" or "legislative" decision, which the courts do not typically review. Lorne Sossin proposes that these decisions should be subject to judicial scrutiny under the Charter and administrative law doctrines, ibid and in "Discretion Unbound", supra note 86. While I agree that the phenomenon of bureaucratic disentitlement threatens the realization of human rights values within administrative agencies, given the limits to rights enforcement explored above, I am skeptical of Sossin's proposal that we turn to courts to ensure administrative policies and practices accord with rights. 


\section{B. Discretion is Pervasive}

Discretion exists wherever uncertainty exists, and uncertainty pervades administrative agencies and legal systems more broadly. Judges use their discretion when deciding difficult cases and members of parliament exercise discretion when crafting laws to regulate social problems. Likewise, administrative decision-makers use discretion when they design social assistance forms, weigh competing policy goals, and interpret and apply statutory and policy provisions to determine whether an individual is eligible for social assistance benefits. A consideration of two related features of discretionary decisions polycentricity and the application of rules - demonstrates how discretion persists despite, or even because of, the tools in place to restrict it.

Discretionary decisions are polycentric in that they require decision-makers to answer questions for which there is no single correct outcome. ${ }^{121}$ Instead, decision-makers may reach a range of reasonable outcomes depending on how they weigh competing or overlapping laws, policies, and legislative objectives and how they apply them to a particular case. Polycentric decisions can arise where a decision-maker is free to choose from a list of options, or between conflicting or overlapping rules. At other times polycentricity is implicit given the vagueness of a particular rule. Appeal to the legislative intent behind the government program does not always resolve this problem. Benefits programs such as social assistance are typically created to achieve competing goals and thus it is rare for the legislation, regulations, and policies governing these programs to be guided by a coherent normative framework. ${ }^{122}$ For instance, Ontario's welfare program is governed by such conflicting objectives as promoting responsibility and self-sufficiency, financially assisting those in need, and remaining accountable to taxpayers. $^{123}$ Similarly, disability benefits are intended to effectively support persons with disabilities, foster a shared responsibility for such support between government, communities, families and individuals, and ensure that only those eligible for disability benefits receive assistance. ${ }^{124}$ Because social assistance programs are founded on competing norms, the front-line workers and policy-makers

121 Here I use "polycentric" to describe this quality of discretionary decisions in a way that diverges from how administrative law case law typically conceives of polycentricity. Cases, such as Baker v Canada (Minister of Citizenship and Immigration), [1999] 2 SCR 817, [1999] SCJ no 39 (QL) at paras 55, 62 [Baker] use polycentricity to refer to those decisions, sometimes called "legislative" decisions, which require the weighing of many different parties' interests. These decisions are distinguished from court-like "judicial" decisions which courts frame as impacting only one party or a small number of parties, as in Canada (Attorney General) v Inuit Tapirisat of Canada, [1980] 2 SCR 735. While some decisions involving competing interests are clearly polycentric in that they require the weighing and harmonizing of conflicting legislative goals, it does not follow that decisions affecting a smaller group of individuals are not also polycentric. In other words, a decision's polycentricity, as I use the term, depends not on the number of parties who may be impacted, but its complexity as a decision given the absence of a single right answer and the presence of numerous legislative or policy goals. Consequently, polycentric decisions can exist in cases where the rights of one party are at issue. Evelyn Z Brodkin, “Accountability in Street-Level Organizations” (2008) 31 Intl J Public Administration 317. $O W A$ at s 1 . See also Janet Mosher, "Intimate Intrusions: Welfare Regulation and Women's Personal Lives" in Shelley Gavigan \& Dorothy Chunn, eds, The Legal Tender of Gender: Welfare, Law and the Regulation of Women's Poverty (Oxford, Portland: Hart Publishing, 2010) 165. 
who bring these programs to life are continually faced with polycentric decisions as they must weigh options and apply competing program objectives as they see fit. ${ }^{125}$

An example illustrates how polycentric decisions can arise in social assistance programs despite the abundance of rules and policies available to guide caseworkers. Questions about documentation requirements, such as the amount and type of documentation needed to determine whether an individual is eligible for social assistance, whether to extend the deadline for producing a particular document, and what sort of additional help, if any, a caseworker will offer to assist an individual in accessing required documents, all involve a range of polycentric decisions. As a condition of receiving benefits, those dependent on social assistance must produce a variety of documents to confirm their identity, assets, income, housing expenses and immigration status. ${ }^{126}$ These documents must be furnished upon applying and periodically to establish ongoing eligibility. While documentation requirements cannot be waived, the policies guiding caseworkers' discretion allow for some flexibility in determining which versions of these documents are acceptable and the means by which a document's authenticity is verified. $^{127}$ In some cases, visual verification is sufficient while in others a photocopy may be required for the applicant's file. Similarly, caseworkers may, but are not obliged to, request that social assistance recipients provide them with new copies of old documents when moving from one office to another or when a new caseworker is assigned to their file. ${ }^{128}$ Caseworkers are also empowered, but not required, to assist particularly vulnerable individuals in obtaining copies of documents. ${ }^{129}$

Whether a document must be an original or a photocopy and whether a caseworker will seek the cooperation of other social services offices or government agencies to obtain copies of hard-to-locate documents are all matters that are left up to a caseworker's discretion. There is no single correct answer in these situations. Caseworkers must balance the competing goals behind social assistance as a program, including the need to support those reliant on assistance and the need to ensure that public funds are only provided to those eligible to receive them, and decide how these goals are best met in a particular case. Discrimination can influence how this discretion is used, for instance, if caseworkers are more skeptical of identity documents provided by racialized minorities as compared to other clients. Conversely, human rights values can also guide the interpretation and application of documentation requirements, for instance, by caseworkers interpreting documentation requirements flexibly to ensure that a homeless client receives benefits for a limited period while a caseworker assists him in obtaining identity documents.

125 Mashaw, supra note 83 at 49-61, identifies this phenomenon in the context of the United States' disability insurance program, noting that this is often done when the legislature itself cannot settle on a cohesive normative framework for a particular social program. $O W A$ at s 7(3)(c); ODSPA at s 5(1).

127 See Ontario Works Policy Directive - 2.1 Application Process (January 2013); Ontario Disability Support Program Income Support Directive - 3.1 Reviewing Eligibility (September 2013), online: Ministry of Community and Social Services $<$ http://www.mcss.gov.on.ca/en/mcss/programs/social/directives/>. Herd \& Mitchell, supra note 38 at 18-19.

129 Indeed, Ian Morrison notes concerns about caseworkers exercising their discretion so that vulnerable applicants, particularly those who are at risk of homelessness, who may not have access to documents verifying their identity or address suffering from stringent documentation requirements: Ian Morrison, "Ontario Works: A Preliminary Assessment" (1998) 13 J L \& Soc Pol'y 1 at 30. 
A second related feature of administrative discretion is that it involves the interpretation and application of rules and guidelines. Despite attempts to standardize administrative decision-making and confine caseworker discretion with a vast array of regulations, "soft" laws, and other administrative tools, ${ }^{130}$ these devices do not eliminate discretion. Front-line workers therefore must still decide how such rules and guidelines apply to a given situation. Additionally, because rules and other regulatory tools cannot cover every possible scenario, they necessarily include gaps that decision-makers fill with their own sense of what is substantively just in a particular situation. Alternatively, a single request for benefits may be addressed by a number of overlapping and potentially conflicting rules or guidelines, requiring that a caseworker sort out which policies should apply. ${ }^{131}$

The vague and general language typical of administrative rules and policies essentially embeds discretion within them. ${ }^{132}$ As noted above, many government benefit programs are not created with one normative goal in mind, but are themselves the product of competing legislative objectives. These objectives are not only reflected in the divergent legislative purposes contained in governing statutes, but in terms such as "reasonable" and "necessary" that are incorporated into the rules and guidelines intended to structure and confine the decisions of front-line workers. ${ }^{133}$ As Madame Justice L'HeureuxDubé noted in Baker, administrative decision-makers must often use "considerable discretion to clarify, fill in legislative gaps, and make choices among various options" when interpreting and applying the regulatory tools that purport to constrain their discretion. ${ }^{134}$ In this way, individuals at the front lines of delivering government benefits retain significant discretion, despite the policies in place to restrict it, and effectively create policy through their interpretation and application of rules, guidelines, and other regulatory tools. ${ }^{135}$

An example taken from welfare regulations demonstrates how embedded discretion operates. These regulations require that caseworkers cancel a welfare recipient's benefits if the recipient fails to do such things as make "reasonable efforts" to seek and maintain employment "for which he or she is physically capable" or to participate in job training activities (which I will refer to collectively as the "reasonable efforts rule"). ${ }^{136}$ A provincial policy sets out the criteria with which reasonableness is assessed. ${ }^{137}$ Caseworkers must, according to this policy, consider whether the individual in question has willfully refused to search for employment or participate in training. The policy also directs caseworkers to consider whether the welfare recipient's failure to meet these requirements fits within a number of listed

130 By "regulatory tools", I include new managerial mechanisms, such as customer service policies, case management software programs, and so on, introduced in an attempt to control how caseworkers go about making decisions.

131 Malcolm M Feeley describes this scenario as being one where the law is "overdetermined": The Process is the Punishment: Handling Cases in a Lower Criminal Court (New York: Russell Sage Foundation, 1979) at xviii. I would argue that, given their proliferation, soft law tools such as administrative rules, guidelines and forms are even more likely to be overdetermined, thus allowing discretion to multiply.

132 Carol Harlow \& Richard Rawlings, Law and Administration, 3d ed (Cambridge: Cambridge University Press, 2009).

133 Roy Sainsbury, "Administrative Justice: Discretion and Procedure in Social Security Decision-Making” in Keith Hawkins, ed, The Uses of Discretion (Oxford: Clarendon Press, 1992) 295.

134 Baker, supra note 127 at para 54.

135 Michael Lipsky, Street-Level Bureaucracy: Dilemmas of the Individual in Public Services (New York: Russell Sage Foundation, 1980) [Lipsky, Street-Level Bureaucracy].

136 OReg 134/98, General, ss 29, 33.

137 Ontario Works Policy Directive 9.1 - Reviewing Eligibility (January 2013) online: Ministry of Community and Social Services $<$ http://www.mcss.gov.on.ca/en/mcss/programs/social/directives/>. 
examples, such as a lack of childcare or an inappropriate "fit" between available programs and her needs. While these examples can help steer a caseworker one way or another, the caseworker is ultimately responsible for determining what is "reasonable" in a given case based on her knowledge of the policy context and the particular welfare recipient. In this way, despite all of the details in this set of rules and guidelines, a caseworker must still assess the reasonableness of her client's efforts, a nuanced task which may not lead to a single correct outcome.

Ironically, because some amount of uncertainty is embedded in the language and structure of rules themselves, caseworker discretion increases in proportion to the number of rules created to constrain it. As part of a wider "deskilling" of the delivery of government benefits, programs such as social assistance have been the sites for a proliferation of rules, guidelines, and other regulatory mechanisms such as checklists, forms, and case management software. ${ }^{138}$ Regulatory tools have expanded in tandem with the intensification of social assistance caseloads and the introduction of customer service standards. ${ }^{139}$ When viewed collectively, however, these devices actually work together to expand caseworker discretion. Front-line workers tend to develop coping strategies when large numbers of rules and guidelines compete with their workplace demands, choosing to apply only those which they perceive as most fundamental. $^{140}$ In other situations, front-line workers may use creative acts of interpretation to bend regulatory tools to meet clients' needs or interpret their clients' circumstances to fit within the bounds of law and policy. ${ }^{141}$ In such cases, the polycentricity of caseworkers' decisions and the vague terms, gapping, and overlapping of the applicable rules and guidelines function together to ensure that discretion flourishes.

The reasonable efforts rule illustrates how caseworker discretion persists despite the policies in place to constrain it. According to this rule, a caseworker must confirm during each client meeting whether her client continues to make reasonable efforts to find work and participate in job training. However, a client may meet with his caseworker to request emergency funding for the replacement of bedding and furniture due to a bed bug infestation, which may require a lengthy assessment to determine whether he is eligible for such funds. ${ }^{142}$ Faced with this emergency assistance request, the complexity of determining whether the same client continues to make reasonable efforts to find work or complete job

138 Simon, supra note 50; see also Vicki Lens, "Bureaucratic Disentitlement after Welfare Reform: Are Fair Hearings the Cure?" (2005) 12:1 Geor J on Poverty L \& Pol'y 13.

139 Christopher J Jewell, Agents of the Welfare State: How Caseworkers Respond to Need in the United States, Germany, and Sweden (New York: Palgrave Macmillan, 2007).

140 Lipsky, Street-Level Bureaucracy, supra note 141 at 14. John Braithwaite also identifies this phenomenon in the case of American nursing home inspectors: John Braithwaite, "Rules and Principles: A Theory of Legal Certainty" (2002) 27 Australian J Leg Philosophy 47.

141 Jeffrey Manditch Prottas, People Processing: The Street-Level Bureaucrat in Public Service Bureaucracies (Lexington, Mass: Lexington Books, 1979) at 91-3, 166.

142 Discrete funding to replace furniture and bedding due to a bed bug infestation was at one time provided through the provincial Community Start-Up and Maintenance Benefit (CSUMB) to both welfare and disability benefits recipients in Ontario. However, this benefit was revoked as of January 1, 2013. Some municipalities have replaced CSUMB with their own municipally-funded benefits. These often require a series of determinations, such as whether an exterminator has treated the client's dwelling, other available funding sources, and the client's family size. For instance, see the City of Toronto's Housing Stabilization Fund, online: City of Toronto $<$ http:/www1.toronto.ca/wps/portal/contentonly?vgnextoid=b577d08099380410VgnVCM10000071d60f89RCRD\#HSF amounts $>$. 
training, and the pressure to manage her caseload of 120 other clients, a caseworker may end up applying only those rules or parts of rules she determines to be most fundamental (by ensuring that her client is signed up for an upcoming resume workshop but not inquiring about the client's job applications, for instance), read "reasonableness" broadly to provide her client with some leeway given the bed bug infestation he is facing, or interpret her client's actions flexibly to fit within one of the rule's exceptions (if her client's circumstances could pass as unique, then perhaps there are presently no training opportunities available to meet his needs). In some cases, the caseworker may ignore the reasonable efforts rule altogether and assume that her client is doing what he can to meet its requirements.

Polycentric decisions and vague, multiple rules thus ensure that discretion flourishes in programs such as social assistance. While caseworkers may use their discretion to make client-supportive decisions, discretion can also allow discrimination to influence caseworkers' decisions. This danger is particularly acute when caseworkers are sandwiched between client demands for much-needed assistance and management demands for efficiently-managed caseloads and improved customer service. Given that discretion is pervasive and flexible, it is worth exploring how it might be harnessed so as to transform the relationship between those reliant on social assistance and those responsible for delivering benefits. In other words, how might discretion provide a space for human rights values, such as dignity and respect, to reshape the delivery of government benefits? The balance of this article offers some preliminary thoughts.

\section{Discretion's Promise}

As noted in Part III, a central problem with rights enforcement is that it does little to alter the relationship between social assistance recipients and those who are responsible for delivering benefits. The unequal relationship between these actors can make any victories achieved through rights enforcement efforts fleeting at best. Further, rights enforcement does not effectively address the many ways in which discretionary decisions can allow discrimination to subtly shape how social assistance is provided to and experienced by some of the most marginalized members of our society. As I have explored throughout this section, discretion is endemic in government benefits programs. While it may be dangerous, discretion also gives policy writers, office managers and front-line workers the freedom to use human rights values as a guide for their individual eligibility and institutional design decisions. It is this very dualism - discretion as a tool for arbitrary decision-making and a mechanism for ensuring individualized, client-supportive decisions - that demands rights realization efforts take up the challenge and promise of discretion.

Discrimination can shade both individual and institutional exercises of discretion in ways that are nearly impossible to counter using rights enforcement strategies. At an individual level, caseworkers may apply rules strictly or flexibly to deny benefits to some clients while granting them to others who are similarly-situated, and rights claims to the HRTO or SBT may be legally or practically impossible. ${ }^{143}$ Likewise, regulatory tools such as guidelines, forms and social services offices may be designed in ways that favour those social assistance recipients who are able-bodied, possess advanced literacy and numeracy skills, or lack significant caregiving responsibilities. Socio-legal research on administrative

143 Robert E Goodin, "Welfare, Rights and Discretion” (1986) 6:2 Oxford J Legal Stud 232. 
decision-makers suggests that discretion is often guided by norms and beliefs about what is fair, but also that such beliefs can be inconsistent and elusive. ${ }^{144}$ Discrimination can easily and imperceptibly infiltrate discretionary decisions because such decisions are often based on intuition. ${ }^{145}$ Yet empirical research into front-line decision-making indicates that values such as fairness and respect may just as easily influence discretionary decisions as individual prejudices. ${ }^{146}$ Not only can this aspect of administrative decision-making be unconscious on the part of those making decisions, but it can be virtually imperceptible to those who are affected by a particular decision. ${ }^{147}$

Despite its dangers, discretion offers promising opportunities for human rights values to permeate administrative agencies. As set out above, because many administrative decisions are polycentric and trigger the application of a plethora of vaguely-worded, intersecting rules, administrative actors actually have a great deal of flexibility in their decisions about individual benefits and the broader institutional delivery of social assistance. Discretion is not just pervasive because of how government benefits programs and policies are structured, but because it is essential to the very functioning of programs like social assistance which purport to tailor benefits to individual clients' circumstances. ${ }^{148}$ If human rights values were used to guide discretionary decisions so that individual and institutional decisions better support those who rely on social assistance, not only might broad goals like dignity and respect become more tangible but social assistance programs themselves may more successfully address clients' needs. The more difficult question is arguably not whether there is a role for human rights values to play as guides for discretion, but how such values might be integrated into administrative agencies as influential social and institutional norms.

Infusing administrative decision-making with human rights values involves change at both individual and institutional levels. At the level of individual discretion, caseworkers could incorporate human rights values into their decision-making processes so that they consider how such values are implicated when making polycentric decisions or applying unclear or overlapping rules. In this way, human rights values might serve as fundamental guiding principles so that, when caseworkers are overwhelmed by competing policies and workplace pressures, they resort to broad norms such as respect for clients' dignity to guide their decisions. By asking themselves how a particular decision might best support a client's well-being or her place in a broader community, ${ }^{149}$ human rights values can temper the intuition that is an otherwise dangerous element of discretionary decisions. Obviously, this will not prevent all decision-makers from using their discretion to discriminate against marginalized individuals, and thus rights enforcement strategies will remain important. However, integrating rights into administrative decision-making would be a significant step on the path towards realizing the ameliorative goals of human rights codes.

\footnotetext{
144 Steven Maynard-Moody \& Michael Musheno, "State Agent or Citizen Agent: Two Narratives of Discretion" (2000) 10:2 J-PART 329.

145 Davis, supra note 12 at 5-6.

146 Hannah-Moffat, Maurutto \& Turnbull, supra note 121. See also Steven Maynard-Moody \& Michael Musheno, Cops, Teachers, Counselors: Stories from the Front Lines of Public Service (Ann Arbour: University of Michigan Press, 2003).

147 Indeed, this was discussed in Tranchemontagne, supra note 10 at para 22. See also Handler, "Discretion in Social Welfare", supra note 77.

148 Handler, Conditions of Discretion, supra note 112.

149 Inspiration for these values is taken from the Code's Preamble, part of which is cited at supra note 107.
} 
At the level of institutional discretion, human rights values can also guide administrative design decisions about the regulatory mechanisms and institutional arrangements that shape how social assistance is delivered to those who rely on it. Numerous opportunities exist here for flexible and imaginative thinking about how discretion can be harnessed to foster fairness, dignity, and respect for both those reliant on social assistance and their caseworkers. For instance, policy writers could establish a fundamental guiding principle requiring that caseworkers consider human rights values when making decisions regarding their clients and that, where rules or policies overlap, rights values be used to guide caseworkers' discretion. This guiding principle could extend farther, though, to require that institutional design decisions support the dignity of both social assistance recipients and caseworkers. Infusing institutional discretion with human rights values might involve revising the forms that caseworkers fill out in client interviews and the standardized letters sent to clients so that such documents are accessible to persons with limited language, literacy, or numeracy skills. ${ }^{150}$ Welfare offices might be redesigned to be more accessible and welcoming to clients. In-house training initiatives could draw on human rights principles and client experience so program delivery continually evolves in response to client needs. Caseloads could be reduced and regulatory technologies simplified so that caseworkers are more able to meet their clients in person, listen to them, and make informed polycentric decisions that balance client needs with the competing objectives of social assistance programs and the quasi-constitutional tenets of human rights codes. ${ }^{151}$ These changes could draw on the experience of social assistance recipients and caseworkers, as well as empirical research on the effectiveness of rules, principles, and policies as tools for guiding administrative decision-makers. As with changes targeting individual discretion, these shifts cannot prevent every instance of discrimination. They would, however, go a long way to gradually realizing the broader transformations heralded by human rights codes.

Moving from rights enforcement to rights integration signals an obvious tension between pluralism and reform. Pluralism is frequently used as a strategy to ensure the persistence of a status quo, particularly in administrative law where pluralist and context-specific approaches can function to prevent courts from interfering with the operation of administrative agencies. ${ }^{152}$ Those who seek to reform administrative agencies, by comparison, often appeal to external bodies, such as courts or tribunals, and occasionally to government-appointed task forces, ombudsmen, and commissions. While I do not deny the importance of external review mechanisms as tools for realizing rights, they must not displace other efforts to transform administrative agencies from the inside.

Given the dominance of rights enforcement, rights-based reform efforts often occur at courts and human rights tribunals. I propose, however, that pluralism can also play a part in reshaping the delivery

150 Despite the marginalized population that comprises welfare recipients, including individuals with mental illness, limited language and numeracy skills, and so on, these types of documents remain notoriously difficult to navigate: Herd \& Mitchell, supra note 38 at 8-10.

151 Front-line workers, according to Mashaw, are in the best position to weigh the competing objectives of the programs that they administer and decide how to best achieve those objectives in a particular case: Mashaw, supra note 83 at 171172. The significance of streamlining the hundreds of rules governing social assistance is reflected in some of the caseworker comments quoted in Brighter Prospects, supra note 9, as well as the recommendations at 16, 20.

152 Indeed, John Willis' work, which favoured pluralism in the face of the McRuer Commission's Report's reformist goals, can be read as favouring the administrative status quo at the time he was writing. For a review of Willis' position, see David J Mullan, "Willis v. McRuer: A Long-Overdue Replay with the Possibility of a Penalty Shoot-Out" (2005) 55:3 UTLJ 535. 
of government benefits. Attempts at achieving uniformity within administrative agencies, reflected in the overwhelming number of rules and policies introduced to constrain front-line workers, are part of the problem. Discretion and uncertainty are not necessary evils, but administrative realities, which pose both challenges and creative opportunities. ${ }^{153}$ If human rights values were to thrive in varied administrative contexts, they may very well be realized differently from one government benefits program to the next while still achieving the broad goals underlying human rights codes. ${ }^{154}$ Coming to terms with this possibility requires more than simply agreeing that a range of fair procedures or reasonable decisions might be acceptable in a particular case: it requires a search for and endorsement of the pluralism of both administrative and human rights law. ${ }^{155}$ Further exploring the nuances of administrative decision-making, including the ways in which institutional discretion can support rights integration and the conditions that might contribute to improved caseworker decision-making, would go a long way towards securing human rights values as a guide for government benefits decisions.

\section{CONCLUSION}

A new approach is needed to realize human rights values in the context of government benefits programs. Rather than rely on rights enforcement, which has proven itself to be a less than effective mechanism for realizing rights, attention must be dedicated to exploring the ways in which individual and institutional discretionary decisions can be infused with human rights values. Given their quasiconstitutional status, such values have a key role to play in shaping the design of administrative agencies and the everyday decisions of front-line workers.

The project of rights integration is obviously challenging, particularly in a climate where pressures to decrease government spending are constant and distrust of public institutions is in vogue. It may be even more of a challenge to integrate human rights into programs, such as social assistance, that have a long history of penalizing the poor for their poverty. ${ }^{156}$ Nonetheless, there is a growing realization that poverty is structural, that people who rely on social assistance do not choose to be poor, and that rights enforcement has been less than effective at improving the lives of our most vulnerable members of society. The time is right to embrace the challenge of rights integration and reimagine the role that human rights can, and should, play in administrative decision-making.

153 Handler, Conditions of Discretion, supra note 112.

154 Braithwaite, supra note 146, acknowledges that broad principles can lead to more certain and coherent results than multiple rules, particularly in complex administrative settings.

155 Here, I am drawing on observations Harry Arthurs made many years ago: Harry W Arthurs, "Rethinking Administrative Law: A Slightly Dicey Business" (1979) 17:1 Osgoode Hall LJ 1.

156 For an overview of the role of morality in the American context, see Joel F Handler \& Yeheskel Hasenfeld, Blame Welfare, Ignore Poverty and Inequality (Cambridge: Cambridge University Press, 2007). For a review of the role that morality has played in Canadian welfare law, see Shelley AM Gavigan and Dorothy E Chunn, "Women, the State and Welfare Law: The Canadian Experience" in Gavigan \& Chunn, eds, The Legal Tender of Gender: Welfare, Law and the Regulation of Women's Poverty (Oxford, Portland: Hart Publishing, 2010) 47. 